\title{
Interleukin-22 Signaling in the Regulation of Intestinal Health and Disease
}

OPEN ACCESS

Edited by:

Eiman Aleem,

Phoenix Childrens Hospital and University of Arizona College of

Medicine-Phoenix, USA

Reviewed by:

Lauren A. Zenewicz,

The University of Oklahoma Health

Sciences Center, USA Régis Josien,

Nantes University Medical School,

France

${ }^{*}$ Correspondence:

Misty Good

goodm/3@upmc.edu

Specialty section:

This article was submitted to

Cell Growth and Division,

a section of the journa

Frontiers in Cell and Developmental

Biology

Received: 14 August 2015

Accepted: 14 December 2015

Published: 13 January 2016

Citation:

Parks OB, Pociask DA, Hodzic Z,

Kolls JK and Good M (2016)

Interleukin-22 Signaling in the

Regulation of Intestinal Health and

Disease. Front. Cell Dev. Biol. 3:85.

doi: 10.3389/fcell.2015.00085

\begin{abstract}
Olivia B. Parks ${ }^{1}$, Derek A. Pociask ${ }^{1,2}$, Zerina Hodzic ${ }^{1}$, Jay K. Kolls ${ }^{1,2}$ and Misty Good ${ }^{1,3 *}$
1 Department of Pediatrics, University of Pittsburgh School of Medicine, Pittsburgh, PA, USA, ${ }^{2}$ Department of Pediatrics, Richard King Mellon Foundation Institute for Pediatric Research, University of Pittsburgh School of Medicine, Pittsburgh, PA, USA, ${ }^{3}$ Division of Newborn Medicine, Department of Pediatrics, Children's Hospital of Pittsburgh, University of Pittsburgh School of Medicine, Pittsburgh, PA, USA
\end{abstract}

Interleukin (IL)-22 is a member of the IL-10 family of cytokines that has been extensively studied since its discovery in 2000. This review article aims to describe the cellular sources and signaling pathways of this cytokine as well as the functions of IL-22 in the intestine. In addition, this article describes the roles of IL-22 in the pathogenesis of several gastrointestinal diseases, including inhibition of inflammation and barrier defense against pathogens within the intestine. Since many of the functions of IL-22 in the intestine are incompletely understood, this review is meant to assess our current understanding of the roles of IL-22 and provide new opportunities for inquiry to improve human intestinal health and disease.

Keywords: interleukin-22, gastrointestinal tract, epithelial cells, barrier defense

\section{INTRODUCTION}

Since its discovery in 2000 (Dumoutier et al., 2000a), interleukin-22 (IL-22) has been widely studied for its diverse roles in cell proliferation, tissue regeneration, cellular defense, and inflammation. IL22 is expressed by inflammatory cells in a number of tissues in the body including the lungs, liver, kidneys, thymus, pancreas, breast, gut, skin, and synovium, reviewed in Dudakov et al. (2015). The focus of this review article is on the distinct roles of IL-22 within the intestine. One of the main functions of IL-22 is to support and maintain the gastrointestinal (GI) epithelial barrier as well as to facilitate barrier defense mechanisms against bacterial pathogens such as Clostridium difficile (Hasegawa et al., 2014), Citrobacter rodentium (Zheng et al., 2008; Muñoz et al., 2015), and Toxoplasma gondii (Muñoz et al., 2015). Studies have shown that regulation of IL-22 is an important component of many diseases including graft-versus-host disease (GVHD) (Munneke et al., 2014), inflammatory bowel disease (IBD), specifically Crohn's disease (Wolk et al., 2007; Schmechel et al., 2008; Souza et al., 2013), ulcerative colitis and the experimental model of ulcerative colitis dextran sodium sulfate (DSS)-induced colitis (Sugimoto et al., 2008) as well as acute polymicrobial sepsis (Weber et al., 2007). The diverse effects of IL-22 against several inflammatory conditions implicate IL-22 as a promising therapeutic target for these types of GI-related illnesses. The purpose of this review article is to describe the distinct roles of IL-22 in the regulation of health and disease in the intestine. 


\section{CELLULAR SOURCES OF IL-22}

IL-22 is a member of the IL-10 family and has recently been grouped into a smaller subset of cytokines called the IL-20 subfamily, which is comprised of IL-19, IL-20, IL-22, IL-24, and IL-26 (Ouyang et al., 2011; Rutz et al., 2014). This family was identified based on their cellular targets and ability to recognize similar receptor subunits.

Many different types of immune cells produce IL-22. In lymphoid tissues, $\alpha \beta$ and $\gamma \delta$ T cells, innate lymphoid cells (ILCs; Cella et al., 2009; Colonna, 2009; Cella et al., 2010; Sonnenberg et al., 2011a; Hanash et al., 2012; Lee et al., 2012; Spits et al., 2013; Korn et al., 2014) and NK T cells (NKTs) all produce IL-22. In addition to the IL-22 produced in lymphoid tissue, macrophages, neutrophils (Zindl et al., 2013; Lee et al., 2015), dendritic cells (Mann et al., 2014), and fibroblasts (Ikeuchi et al., 2005) have also been identified as sources for IL-22; however, these nonlymphoid sources produce less IL-22 relative to the lymphoid sources. Depending on the tissue type, other non-traditional cell types can produce IL-22. For example, in the gastrointestinal tract of mice with experimental colitis, neutrophils become activated and are subsequently capable of expressing IL-22 (Zindl et al., 2013; Lee et al., 2015). In a mouse model of DSS-induced colitis, Zindl et al. demonstrated that depletion of Ly6G/C $\mathrm{C}^{+}$ neutrophils/dendritic cells using RB6-8C antibody resulted in reduced colonic levels of IL-22, and additionally, these isolated colonic neutrophils were capable of producing IL-22 after IL-23 stimulation (Zindl et al., 2013). In a mouse model of infectious colitis, Lee and colleagues found the $\mathrm{CD}_{11 b^{+}} \mathrm{Ly}_{6 \mathrm{C}}{ }^{+} \mathrm{Ly}_{6 \mathrm{G}}{ }^{+}$ subset of neutrophils were the main source of IL-22 secretion (Lee et al., 2015). This type of non-traditional expression of IL22 can be found in patients with diseases outside the GI tract such as rheumatoid arthritis (RA), where fibroblasts have been found to contribute to the production of IL-22 (Ikeuchi et al., 2005). Accordingly, cellular sources of IL-22 are numerous, and the main production sites of IL-22 in lymphoid-derived cells are described below:

\section{$\alpha \beta$ T Cells}

IL-22 production has been demonstrated by three subtypes of $\mathrm{T}$ helper (Th) cells: Th1, Th17, and Th22. The prototypical IFN$\gamma$ producing Th1 cells can produce IL-22 without additional growth factors during effector function. However, naive T cells require the presence of transforming growth factor- $\beta$ (TGF- $\beta$ ) to drive either the formation of Th17 cells, which can then produce IL-22, and/or T regulatory cells (Tregs; Littman and Rudensky, 2010). The cytokine IL-6 drives the expression of retinoic acid-related orphan receptor- $\gamma \mathrm{t}(\mathrm{ROR} \gamma \mathrm{t})$ and IL-23, both of which are critical for Th17 cells to produce IL-22 (Zhou et al., 2007). The regulation of Th17 cells is further controlled by changes in the concentration of TGF- $\beta$ (Zhou et al., 2008). When the concentration of TGF- $\beta$ is low, Th17 cells are induced via IL-23-stabilization of ROR $\gamma t$ (Zhou et al., 2008). However, when TGF- $\beta$ is present in high concentrations, expression of the IL-23 receptor is inhibited, reducing the expression of both ROR $\gamma \mathrm{t}$ and IL-22, while also activating the transcription factor forkhead box P3 (FoxP3; Zhou et al., 2008). This leads to the expansion of Tregs. Thus, high concentration of TGF- $\beta$ promotes
Treg expansion while preventing further expansion of Th17 cells (Zhou et al., 2008). This TGF- $\beta$ dependent suppression of IL-22 was found to be mediated by c-Maf, a transcription factor that binds to the IL-22 promoter (Rutz et al., 2011). Furthermore, IL23 can counteract the effects of high concentrations of TGF- $\beta$ by inducing production of IL-22 (Zhou et al., 2008).

Th22 cells also produce IL-22 and were first identified in the skin as a helper T cell population expressing CCR6, CCR4, and CCR10 (Duhen et al., 2009; Trifari et al., 2009). Th22 cells are classified as a subset of $\mathrm{CD} 4^{+}$helper $\mathrm{T}$ cells characterized for their production of IL-22, IL-13, and tumor necrosis factor (TNF)- $\alpha$, but not IL-17, IFN- $\gamma$, or IL-4 (Duhen et al., 2009). Th22 cells are further described by their inability to produce T-bet (a transcription factor known to control IFN- $\gamma$ ) and negligible expression of ROR $\gamma \mathrm{t}$ (a Th17 and IL-22 transcription factor; Duhen et al., 2009). However, the development of CD4+ T cells capable of producing IL-22 is dependent on the aryl hydrocarbon receptor (AhR) and T-bet (Basu et al., 2012). Moreover, a recent study has demonstrated that activation of signal transducer and activator of transcription factor 3 (STAT3) was required for IL-22 production by Th22 cells and was responsible for effective host clearance of infectious colitis (Backert et al., 2014).

\section{$\gamma \delta$ T Cells}

$\gamma \delta \mathrm{T}$ cells are found in the intraepithelial lymphocyte (IEL) compartment of the intestine and secrete a variety of cytokines, including a significant amount of IL-22 (Sutton et al., 2009). $\gamma \delta$ and $\alpha \beta$ T cells share two features in common: (1) expression of ROR $\gamma t$ and (2) expression of IL-22 in the presence of IL-23 (Martin et al., 2009; Sutton et al., 2009; Mabuchi et al., 2011; Mielke et al., 2013). Certain types of $\gamma \delta$ T cells express Toll-like receptors (TLRs) and can directly interact with specific pathogen products (Martin et al., 2009; Crellin et al., 2010).

$\gamma \delta \mathrm{T}$ cells have roles in limiting the translocation of pathogens such as Salmonella typhimurium and T. gondii in the intestinal epithelial tissue (Edelblum et al., 2015). The $\gamma \delta$ IELs contribute to the regulation and maintenance of gut homeostasis (Fuell et al., 2015). Studies have shown that mice deficient in $\gamma \delta$ IELs (T Cell Receptor $\delta^{-/-}$mice) have structural differences within their intestine compared to wild-type littermates, including altered intestinal glycosylation and glycan antennae (Fuell et al., 2015). These structural differences can contribute to a lack of mucosal protection in the gut of mice deficient in $\gamma \delta$ IELs, indicating $\gamma \delta$ IELs and $\gamma \delta$ T cells play a role in intestinal host defense (Edelblum et al., 2015; Fuell et al., 2015).

\section{Innate Lymphoid Cells (ILCs)}

ILCs contribute to the innate and adaptive immunity of the intestine and can be found at mucosal surfaces or in cryptopatches, which are found in the lamina propria of the small intestine beneath the intestinal crypts (Diefenbach, 2012). ILCs are characterized by their lymphoid morphology, absence of cytotoxic capacity, and lack of B or T cell receptors as reviewed in Spits and Cupedo (2012) and Spits et al. (2013). ILCs are a relatively recent addition to the immune cell family and are grouped based on their functional characteristics and expression of cytokines and transcription factors (Spits et al., 2013). Group 1 ILC (ILC1s), defined by their expression of the transcription 
factor T-bet, produce the Th1 cytokine IFN- $\gamma$ and are critical to host response of intracellular infections (Klose et al., 2014). Group 2 ILCs (ILC2s) are dependent on the transcription factor GATA3 to produce the Th2 cytokines IL-5 and IL-13 (Hoyler et al., 2012) and are important in helminth infection (Fallon et al., 2006). Group 3 ILC (ILC3s) are defined by their expression of ROR $\gamma \mathrm{t}$, production of the Th17 cytokines IL-17 and IL-22, and involvement in defense against extracellular bacterial or fungal infections (Sonnenberg et al., 2011b; Gladiator et al., 2013; Edelblum et al., 2015) as described in Table 1 (Eberl et al., 2015).

Moreover, $\mathrm{CD} 4^{+} \mathrm{T}$ cells can regulate ILC production of IL-22 as well as downstream production of antimicrobial peptides (AMPs) in an IFN- $\gamma$ dependent manner (Korn et al., 2014). The AMPs evaluated in this study were regenerating islet derived $3(\operatorname{Reg} 3) \gamma$ and $\beta$, members of the C-type lectin family (Gallo and Hooper, 2012), which are induced by IL-22 (Kolls et al., 2008; Zheng et al., 2008). Reg3 $\beta$ has been reported to kill Escherichia coli and may be involved in creating a niche of invading pathogens, specifically $S$. typhimurium (Stelter et al., 2011). In contrast, the related protein $\operatorname{Reg} 3 \gamma$, which binds to peptidoglycan, has bactericidal activity against Gram-positive bacteria (Cash et al., 2006) and maintains a physical space between luminal bacteria and the epithelium (Vaishnava et al., 2011).

ILC3s can be found in the small and large intestinal mucosa, Peyer's patches and gut-associated lymphoid tissue (GALT; Cella et al., 2014). ILC3s include lymphoid tissue-inducer (LTi) cells and ILC3s that can be activated to express IL-22 by IL-23 through natural cytotoxicity receptor $(\mathrm{NCR})^{+}$and $\mathrm{NCR}^{-}$ILC3s (Spits and Cupedo, 2012; Spits et al., 2013). In both humans and mice, $\mathrm{NCR}^{+}$ILC3s do not produce IFN- $\gamma$, which promote NK cell function, differing these cells from typical NK cells (Colonna, 2009; Cella et al., 2010; Spits et al., 2013). In addition, IL-15 and ROR $\gamma \mathrm{t}$ are essential for the development and maturation of $\mathrm{NCR}^{+}$ILC3s (Satoh-Takayama et al., 2008; Cella et al., 2009; Luci et al., 2009; Sanos et al., 2009).

TABLE 1 | Description of the different types of innate lymphoid cells (ILCs).

\begin{tabular}{|c|c|c|c|c|}
\hline \multicolumn{5}{|c|}{ Innate Lymphoid Cells } \\
\hline $\begin{array}{l}\text { Cell } \\
\text { Type }\end{array}$ & $\begin{array}{l}\text { Immunologic } \\
\text { function }\end{array}$ & Stimulation & $\begin{array}{l}\text { Transcription } \\
\text { factors }\end{array}$ & $\begin{array}{l}\text { Effector } \\
\text { cytokines }\end{array}$ \\
\hline ILC1 & $\begin{array}{l}\text { Intestinal } \\
\text { inflammation }\end{array}$ & $\begin{array}{l}\text { IL-12 } \\
\text { IL-15 } \\
\text { IL-18 }\end{array}$ & T-bet & $\begin{array}{l}\text { IFN- } \gamma \\
\text { TNF- } \alpha\end{array}$ \\
\hline ILC2 & $\begin{array}{l}\text { Airway } \\
\text { inflammation } \\
\text { Helminth } \\
\text { infection }\end{array}$ & $\begin{array}{l}\text { IL-25 } \\
\text { IL-33 } \\
\text { TSLP }\end{array}$ & $\begin{array}{l}\text { ROR } \alpha \\
\text { GATA3 } \\
\text { Bcl11b }\end{array}$ & $\begin{array}{l}\mathrm{IL}-4 \\
\mathrm{IL}-5 \\
\mathrm{IL}-13\end{array}$ \\
\hline ILC3 & $\begin{array}{l}\text { Intestinal } \\
\text { inflammation } \\
\text { Gut barrier } \\
\text { protection } \\
\text { Lymphoid } \\
\text { tissue } \\
\text { development }\end{array}$ & $\begin{array}{l}\text { IL-23 } \\
\text { IL-1 } 1 \beta\end{array}$ & $\begin{array}{l}\text { ROR } \gamma t \\
\text { AhR }\end{array}$ & $\begin{array}{l}\text { IL-17 } \\
\text { IL-22 } \\
\text { LT- } \alpha_{1} \beta_{2} \\
\text { GM-CSF }\end{array}$ \\
\hline
\end{tabular}

\section{Natural Killer T Cells}

All Natural Killer T (NKT) cells develop and mature in the thymus where they diverge from other cell types at the $\mathrm{CD} 4^{+} \mathrm{CD} 8^{+}$double positive thymocyte stage (Mebius et al., 2001; Bendelac et al., 2007; Possot et al., 2011). Before this thymocyte stage, the $\alpha \beta$ T cell receptor (TCR) of undifferentiated cells must recombine to bind to a CD1d molecule to progress developmentally (Bendelac et al., 2007). The NKT cell developmental cycle has unique stages of development (Bendelac et al., 2007; Godfrey et al., 2010) based on the NKT cells expression of CD24, CD44, or NK1.1 as well as the transcription factors PLZF, c-Myc, Egr2, RelA, or T-bet (Bendelac et al., 2007; Godfrey et al., 2010). NKT cells that produce IL-22 are also known to express CCR6, IL-23R, ROR $\gamma \mathrm{t}$, paralleling $\gamma \delta \mathrm{T}$ cells, Th17 cells, and ILC3s (Bendelac et al., 2007; Godfrey et al., 2010). In addition, NKT cells produce IL-22 in the presence of IL-23 (Rachitskaya et al., 2008; Doisne et al., 2011; Moreira-Teixeira et al., 2011; Paget et al., 2012). Accordingly, NKT cells are similar to ILCs and $\gamma \delta \mathrm{T}$ cells in that these cell types can produce IL22 without transcriptional activator interferon regulatory factor 4 (IRF4) signaling, whereas $\alpha \beta \mathrm{T}$ cells require IRF4 signaling to initiate IL-22 expression (Raifer et al., 2012). However, IL22-producing NKT cells have been found to require interaction from TCR-CD1d to induce production of IL-22 (Doisne et al., 2011). Many details surrounding NKT cells that produce IL-22 are not well understood. A study has suggested that a stage during NKT cell development called "stage 0" (CD24 $\left.{ }^{+} \mathrm{CD} 44^{\mathrm{lo}} \mathrm{NK} 1.1^{-}\right)$ is crucial to the maturation of these cells and is hypothesized to be controlled by ROR $\gamma t$ (Benlagha et al., 2005); however, further studies are needed to completely understand the role of NKT cells in IL-22 production.

\section{POSITIVE AND NEGATIVE REGULATORS OF IL-22}

IL-22 is mainly produced by Th17 cells, ILCs, $\gamma \delta \mathrm{T}$ cells, and NKT cells (Ouyang et al., 2011). Th17 cells produce IL-22 in response to IL- 6 and TNF- $\alpha$ in the setting of inflammation and trauma (Liang et al., 2006; Zhang et al., 2011). However, IL-6 can independently initiate the expression of IL-22 (Liang et al., 2006; Zheng et al., 2007). Il-22 gene expression, initially found only in the thymus and brain (Dumoutier et al., 2000a,b; Sabat et al., 2014), has been discovered in the gastrointestinal tract, liver, lung, skin, pancreas, and spleen (Sabat et al., 2014). IL-22 expression and production is positively and negatively regulated by several molecules including IL-23, IL-7, the Notch signaling pathway, the AhR, IL-22 binding protein (IL-22BP), IL-25, and IL-1 $\beta$. Our continued study of these molecules can aid in the understanding IL-22, particularly in the setting of gastrointestinal disease.

\section{Interleukin-23}

IL-23 is one of the main inducers of the expression and production of IL-22 (Kastelein et al., 2007). During differentiation of Th17 cells, IL-23 enhances IL-22 expression, which leads to increased expression of the IL-23 Receptor (IL-23R). This results in enhanced interaction between IL-23 and its receptor, and consequently, increased IL-22 production. 
Activated dendritic cells (DCs) and macrophages, in response to microbial stimulation, are important sources of IL-23 (Langrish et al., 2004). IL-23 production by DCs is regulated by the lymphotoxin- $\beta$ receptor (LT $\beta$ R; Tumanov et al., 2011). IL-23 production by activated DCs via LTBR indirectly results in increased IL-22 by RORyt+ ILCs (Tumanov et al., 2011).

However, there are other cellular sources of IL-23. DSSinduced epithelial injury results in activation of LT $\beta$ R signaling, which promotes intestinal mucosal healing by triggering production of IL-23 from intestinal epithelial cells (MachoFernandez et al., 2015). This ultimately results in increased IL-22 production by RORyt+ ILC3s, particularly CCR6+Tbet- CD4and CD4+ LTi cells (Macho-Fernandez et al., 2015).

\section{Interleukin-7}

IL-7, a critical cytokine for the maintenance, development, and proliferation of $\alpha \beta$ and $\gamma \delta$ T cells, also acts to positively regulate the production of IL-22 (Cella et al., 2010). It is unlikely that the cytokine IL-7 directly regulates the expression of IL-22; however, IL-7 is necessary for the stable expression of ROR $\gamma \mathrm{t}$, a transcription factor important in IL-22 expression (Vonarbourg et al., 2010). ROR $\gamma t$ expression regulates the differentiation of cells that produce IL-22 to achieve the optimal conditions for the production of IL-22 (Nurieva et al., 2007; Qiu et al., 2012). These observations would suggest that IL-7 acts in an expansion role to promote the expression of IL-22 by many types of cells. However, IL-7 is not directly required for functional IL-22 cytokine to be produced in tissues (Peschon et al., 1994; von Freeden-Jeffry et al., 1995; Nurieva et al., 2007; Vonarbourg et al., 2010; Qiu et al., 2012).

\section{Notch}

Notch-induced stimulation of $\mathrm{CD}^{+} \mathrm{T}$ cells increases the production of IL-22 within the intestine, which is important for epithelial cell proliferation and differentiation (Murano et al., 2014). Overexpression of Hes1, a Notch target gene, enhanced IL-22-induced STAT3 expression in a human intestinal epithelial cell line (Murano et al., 2014). However, in Notch-deficient mice, IL-22 signaling and production was eliminated (Alam et al., 2010; Murano et al., 2014). Lee et al. demonstrated that the Notch receptor was induced by the AhR (Lee et al., 2012), which promotes the development of ILCs and Th17 cells, ultimately leading to increased IL-22 production.

\section{Aryl Hydrocarbon Receptor (AhR)}

The AhR induces IL-22 in one of two ways. AhR can either (1) directly regulate IL-22 gene expression and cytokine production or (2) regulate the production and development of ILC3 and Th17 cells (Veldhoen et al., 2008; Lee et al., 2012; Qiu et al., 2012). AhR is found in the cytoplasm complexed with heat shock protein 90 (Hsp90; Esser et al., 2009), and once activated, the AhR complex can translocate to the nucleus where AhR can act as a transcription factor (Tsuji et al., 2014). Various ligands, physical stress, cyclic AMP, and calcium $\left(\mathrm{Ca}^{2+}\right)$ can all activate AhR. It is thought that AhR ligands derived from gut microbiota are not required for the development of ILCs (Veldhoen et al., 2008; Esser et al., 2009; Qiu et al., 2012). However, these ligands are thought to be an essential component to initiate the transcription of IL-22 (Denison and Nagy, 2003; Oesch-Bartlomowicz et al., 2005; McMillan and Bradfield, 2007; Nguyen and Bradfield, 2008; Puga et al., 2009; Lee et al., 2012; Zelante et al., 2013; Lowe et al., 2014).

\section{Interleukin-1 $\beta$}

IL-1 $\beta$ is an influential cytokine, capable of activating NKT cells, ILC3s, and Th17 cells to produce IL-22 (Sutton et al., 2009; Doisne et al., 2011; Paget et al., 2012; Chen et al., 2013; Lee et al., 2013; Monteiro et al., 2013). Macrophages, DCs, neutrophils, B and $\mathrm{T}$ cells, endothelial cells, and epithelial cells all produce IL$1 \beta$, making this ligand a diverse molecule in cellular pathways (Sims and Smith, 2010). IL-1 $\beta$ production sustains expression of IL-22 in vitro, promotes the expansion of NK cells, specifically, human stage three immature NK cells, in conjunction with IL-15 from secondary lymphoid tissue DCs, and inhibits these NK cells from differentiating into IFN- $\gamma$-producing cells (Sutton et al., 2009). Of note, in IL-1 receptor ${ }^{\text {hi }}$ immature NK cells, IL-1 $\beta$ must be constantly present in order for continual expression of IL-22. This is in direct contrast to IL-23, which only needs to be present to initiate the IL-22 signaling pathway so that IL-22 production continues in the absence of IL-23 (Hughes et al., 2010).

\section{Negative Regulation of IL-22}

There are several molecules that negatively regulate IL-22 expression. IL-22 Binding Protein (IL-22BP, also known as IL22RA2) is a soluble receptor that is able to regulate IL-22 bioactivity, which has a 1000 times higher binding affinity for IL22 compared to the IL-22 receptor (IL-22RA1) complex (Weiss et al., 2004; Wolk et al., 2007). Epithelial expression of IL-25 is able to repress IL-22 production by RORyt+ ILCs (Weiss et al., 2004; Wolk et al., 2007). Transforming growth factor- $\beta$ (TGF- $\beta$ ) has several functions, specifically with respect to Th17 cells, ROR $\gamma$ t, IL-23R, and IL-22 (Mangan et al., 2006; Zhou et al., 2007; Morishima et al., 2009). TGF- $\beta$ is essential for the differentiation of Th17 cells and influences ROR $\gamma$ t and IL-23R expression in various tissues (Morishima et al., 2009). In IL-22 signaling, TGF- $\beta$ acts in a dose-dependent fashion to regulate the expression of IL-22 (Zheng et al., 2007; Volpe et al., 2009; Rutz et al., 2011; Penel-Sotirakis et al., 2012). However, the cytokine IL-23 is able to overcome the effects of TGF- $\beta$ on IL22, thereby increasing production of IL-22 (Volpe et al., 2009; Rutz et al., 2011). Furthermore, both the transcription factor c-Maf (an inhibitor of TGF- $\beta$, IL-22, IL-27) and the inducible costimulator (ICOS) pathways can influence IL-22 production (Bauquet et al., 2009; Paulos et al., 2010; Rutz et al., 2011). A recently described and poorly understood cytokine member of the IL-1 family, IL-38, can also regulate IL-22 production. At low concentrations, IL-38 can prevent the production of IL-22, while at high concentrations, IL-38 promotes the production of IL-22 (Tortola et al., 2012; van de Veerdonk et al., 2012). However, further studies are required to determine the signaling pathways involved with IL-38 and their biologic effects.

\section{IL-22 Binding Protein}

IL-22RA2, alternatively called IL-22BP, has been found throughout the body. It is a soluble secreted receptor with a binding structure similar to the membrane bound IL-22RA1 
(Dumoutier et al., 2001; Wu et al., 2008). This structural homology allows IL-22BP to bind to IL-22, thereby inhibiting the binding of IL-22 to its receptor complex and consequently preventing IL-22 signaling (Wu et al., 2008). Interestingly, it has been observed that IL-22BP levels decrease with significant increases in IL-22 (Weiss et al., 2004; Wolk et al., 2007). IL-22BP levels increase only after persistently high levels of IL-22, indicating that IL-22BP has a regulatory role after the initial effects of the elevated IL-22 levels have been established (Wolk et al., 2007; Sugimoto et al., 2008; Huber et al., 2012). In the intestine, IL-22BP is highly expressed in colonic dendritic cells (Huber et al., 2012). When tissue damage in the intestine is detected, the NLRP3 or NLRP6 inflammasomes down-regulate IL-22BP via activation of IL-18 (Huber et al., 2012). Additionally, Martin et al. discovered a subset of conventional dendritic cells, lamina propria $\mathrm{CD}_{103}{ }^{+} \mathrm{CD} 11 \mathrm{~b}^{+} \mathrm{DCs}$, in both lymphoid and non-lymphoid tissues as a significant source of IL-22BP (Martin et al., 2014). Additionally, eosinophils within the human intestine were also identified as an important source of IL-22BP (Martin et al., 2015).

\section{IL-22 RECEPTOR AND SIGNALING}

The IL-22 receptor is a type 2 cytokine receptor comprised of the heterodimeric complex with IL-22RA1 and IL-10R2 (IL-10R $\beta$; Kotenko et al., 1997, 2001; Xie et al., 2000; Dumoutier et al., 2000c; Li et al., 2004). While IL-10R2 is constitutively expressed in cells throughout the body, IL-22RA1 is expressed almost exclusively in epithelial tissues (Wolk et al., 2004). Due to this specificity of IL-22RA1, it is hypothesized that this receptor has a defining role in facilitating the innate immunity of epithelial cells (Zheng et al., 2007, 2008). Interestingly, IL-22 has been shown to have no affinity for IL-10R2 and rather a very high affinity to bind to IL-22RA1 (Logsdon et al., 2002, 2004; Li et al., 2004; Wolk et al., 2004; Jones et al., 2008; Yoon et al., 2010). Binding of IL22 to IL-22RA1 increases its affinity for IL-10R2 (Logsdon et al., 2002; Li et al., 2004; Logsdon et al., 2004; Wolk et al., 2004; Jones et al., 2008; Yoon et al., 2010), suggesting a stepwise process in the binding (Bleicher et al., 2008).

IL-22 signals through the IL-22 receptor complex, leading to activation of Janus kinase 1 (Jak1) and non-receptor protein tyrosine kinase 2 (Tyk2; Lejeune et al., 2002). This primarily leads to tyrosine residue phosphorylation of STAT3; however, STAT1 and STAT5 have also been shown to be activated by IL-22 (Lejeune et al., 2002). STAT3 activation in the intestinal epithelium is responsible for immune homeostasis as well as wound healing in an IL-22 dependent manner (Pickert et al., 2009). Several additional pathways are involved in IL-22 signaling, including Mitogen Activation Protein Kinase (MAPK), Akt (Sekikawa et al., 2010), and p38 pathways (Andoh et al., 2005).

\section{IL-22 REGULATION OF HEALTH AND DISEASE: GASTROINTESTINAL TRACT}

IL-22 has several roles in the gastrointestinal tract, including tissue regeneration and cell proliferation, defense against pathogens, as well as maintenance and protection of the intestinal barrier. Expression of IL-22 has been identified in the many tissues including the upper GI tract, the oral cavity, salivary glands, tonsils, stomach, and esophagus (Cella et al., 2009; Cupedo et al., 2009; Hughes et al., 2009; Ciccia et al., 2012; Delsing et al., 2012; Kato-Kogoe et al., 2012; Naher et al., 2012; Zhuang et al., 2012). In these tissues, IL-22 induces the production of defensins, Reg family molecules, and S100 proteins-all of which are innate antimicrobial molecules (Wolk et al., 2004, 2006; Liang et al., 2006; Zheng et al., 2008; Pickert et al., 2009; Sanos et al., 2011; Sonnenberg et al., 2012). These antimicrobials assist in providing gut barrier protection against pathogens (Sugimoto et al., 2008). During colitis, IL22 is responsible for regulating mucin production from goblet cells, which constitutes the protective mucous layer that lines the intestinal epithelium (Sugimoto et al., 2008). However, further studies are needed to determine whether the intestinal mucin production is directly or indirectly related to goblet cells influenced by IL-22 expression.

Recent studies have demonstrated that patients with IBD, specifically Crohn's disease or ulcerative colitis have increased IL22 expression in the colonic tissue (Hanash et al., 2012). Wolk et al. found systemically elevated IL-22 in Crohn's disease and intestinal elevation of IL-22 in a mouse model of colitis (Wolk et al., 2007). In both circumstances, LPS-binding protein (LBP) was also found to be upregulated in the blood (Wolk et al., 2007). Moreover, administration of IL-22 to healthy mice resulted in increased LBP at concentrations capable of neutralizing LPS, and consequently, inflammation. This suggests that IL-22 can act as an anti-inflammatory molecule against LPS and may be a novel therapeutic agent in IBD patients (Witte et al., 2010; Sonnenberg et al., 2011a; Sabat et al., 2014).

In patients with IBD, there is significantly decreased expression of $\mathrm{AhR}$ in intestinal tissue, and in response to AhR agonist, 6-formylindolo(3, 2-b) carbazole (Ficz), isolated intestinal lamina propria mononuclear cells in this patient population resulted in increased IL-22 (Monteleone et al., 2011). Moreover, in multiple experimental mouse models of colitis, administration of Ficz subsequently caused IL-22 induction, whereas administration of an AhR antagonist resulted in more severe colitis with decreased IL-22 production (Monteleone et al., 2011).

IL-22 has a critical role in antibacterial immunity and host defense in the intestine. IL-22 is important in the clearance of the mouse pathogen $C$. rodentium, which causes infectious colitis that mimics E. coli infection in humans (Zheng et al., 2008; Sonnenberg et al., 2011b). Furthermore, infectious colitis with C. rodentium can be suppressed with ILC production of IL-22 (Qiu et al., 2012) in an AhR and microbiota-dependent manner (Qiu et al., 2013). This is in accordance with the observation that IL-22 is elevated in the colon in response to infection by C. difficile or C. rodentium (Sonnenberg et al., 2011b). This suppression against $C$. rodentium infection is mediated by ILCs, which are the main sources of IL-22 in the intestine (Hanash et al., 2012). ILCs have also been associated as a source of IL22 for defense against DSS-induced colitis and GI graft-versushost disease (GVHD; Hanash et al., 2012). ILCs have also been 
implicated in the pathogenesis of IBD, as they are present within the inflamed intestinal tissue of patients. Studies by Hepworth et al. demonstrate that ILCs regulate $\mathrm{CD} 4^{+} \mathrm{T}$ cell responses to commensal bacteria within the intestine (Hepworth et al., 2013). Future research is necessary to understand how ILCs manipulate the adaptive immunity to protect against diseases such as IBD. Manipulation of ILCs or the cytokines they produce may provide therapeutic targets in the future for patients with IBD.

IL-22 can also provide pro-inflammatory responses within the intestine. In some cases, such as those involving colonic subepithelial myofibroblasts, increasing IL-22 levels will cause inflammation and hyperproliferation, resulting in negative effects on tissues and the production of pro-inflammatory molecules like IL-1, IL-6, IL-8, IL-11, G-CSF, and GM-CSF (Andoh et al., 2005). Increased IL-22 levels can also recruit pathologic effector cells to the inflamed tissue site, most noticeably in autoimmune diseases in other tissues (Pan et al., 2013).

\section{Host Defense Against Bacterial Pathogens in Intestine}

One important mechanism of host defenses in the intestine against bacterial pathogens are the presence of tight junctions that maintain the integrity of the intestinal epithelium, thereby preventing bacterial translocation (Macdonald and Monteleone, 2005), and notably, IL-22 is capable of maintaining these tight junctions (Kim et al., 2012). In addition to the mucin-secreting goblet cells within the intestine, Paneth cells are able to maintain mucosal integrity against pathogens by releasing AMPs, which help contain microorganisms within the GI tract (Takahashi et al., 2001). Zheng and colleagues investigated the role of IL-22 in protecting colonic tissue from infectious colitis with $C$. rodentium (Zheng et al., 2008), paralleling infection by enterohemorrhagic E. coli (EHEC), and enteropathogenic E. coli (EPEC) in humans (Mead and Griffin, 1998). EHEC and EPEC both cause infectious diarrhea and carry a high morbidity and mortality, most noticeably in infants and children in developing countries (Zheng et al., 2008). The murine pathogen $C$. rodentium provides an experimental model of infectious colitis in mice. Zheng et al. compared IL-22-deficient mice to wild-type mice infected with C. rodentium and found that IL-22-deficient mice had $80-100 \%$ mortality during the second week post-infection (Zheng et al., 2008). Wild-type mice in response to infection by $C$. rodentium initially experienced weight loss, but were able to make a full recovery from the infection after $\sim 6$ days (Zheng et al., 2008). Histological analysis of these two groups revealed increased colonic mucosal hyperplasia and increased inflammation in the submucosal tissue in IL-22-deficient mice compared to the wildtype mice (Zheng et al., 2008). Moreover, the site of infection by C. rodentium differed in the two groups of mice (Zheng et al., 2008). In the IL-22-deficient mice, bacteria were found deep in the colonic tissue, whereas bacteria in wild-type mice were limited to the superficial layer of the epithelial tissue (Zheng et al., 2008). Furthermore, the authors concluded that IL-22 is the only indispensable cytokine necessary to ensure host defense against C. rodentium during the early stages of the infection as opposed to IL-17A, IL-17F, IL-19, IL-20, and IL-24 (Zheng et al., 2008). If IL-22 is absent during initial infection by C. rodentium, IL-22 does not provide adequate protection against the bacteria (Zheng et al., 2008). IL-22 knock-out mice infected with C. rodentium that were administered IL-22 several days after infection had a high mortality rate compared to infected mice administered IL-22 at the beginning of infection (Zheng et al., 2008). This data is a strong indication that IL-22 is an important cytokine in protecting intestinal epithelial tissue from bacterial pathogens and may provide a therapeutic opportunity against EHEC and EPEC infectious colitis in humans (Zheng et al., 2008).

The microbiota within the intestine contain pathobionts, which are commensal bacteria that can become virulent when homeostasis is disrupted (Hasegawa et al., 2014). For example, when intestinal epithelial tissue is infected with the pathogen C. difficile, pathobionts are capable of translocating to other tissues, thereby spreading the infection (Hasegawa et al., 2014). However, IL-22 can control the elimination of enterobacterial pathobionts by facilitating the binding of $\mathrm{C} 3$ of the complement pathway to bacteria (Hasegawa et al., 2014). Since little is understood about immune mechanisms in defense against these pathobionts, the discovery of the role IL-22 plays in controlling the pathobionts is important.

\section{IL-22 and Fucosylation in the Intestine}

Recently, the IL-22RA1 receptor has also been shown to mediate protection against $C$. rodentium infection in the intestine (Pham et al., 2014). Mice deficient in IL-22RA1 had increased epithelial bacterial translocation of Enterococcus faecalis compared to littermate controls. When fucosylated oligosaccharides were administered to the $C$. rodentium-infected IL-22RA1-deficient mice, infection was attenuated and the bacterial diversity of commensals was restored, demonstrating that IL-22RA1 mediates antimicrobial activities and intestinal fucosylation as in Figure 1 and (Pham et al., 2014). Intestinal epithelial cell fucosylation is catalyzed by fucosyltransferase 2 (Fut2) and is a symbiotic mechanism of host-microbiota interaction, as many bacteria utilize epithelial fucose as a source of dietary carbohydrate (Pacheco et al., 2012; Goto et al., 2014). Pickard et al. demonstrated that Fut2 was expressed by IL-22-stimulated intestinal epithelial cells in the intestine and that fucosylation of the intestinal epithelium occurred in response to Toll-like receptor ligand exposure (Pickard et al., 2014).

Segmented filamentous bacteria (SFB) are an intestinal commensal bacteria in mice that can induce IL-22 expression (Ivanov et al., 2009). Fucosylation in the ileum of SFB-colonized mice has been shown to be dependent on IL-22 and the TNF family member lymphotoxin $\alpha$ (LT $\alpha$; Goto et al., 2014). IL-22 and LT $\alpha$ are produced by ILC3s to mediate intestinal fucosylation demonstrating that ILC3s may control the intestinal commensals by this mechanism (Goto et al., 2014).

\section{Graft-versus-Host Disease (GVHD)}

Graft versus host disease can occur after donor $\mathrm{T}$ cells are activated against antigens from the recipient and subsequently attack various organs such as the intestinal tract (Hanash et al., 2012). Multiple investigators have shown that IL-22 derived from the recipient in the liver and GI tract have been shown to reduce mortality and tissue pathology, whereas donor-derived IL-22 


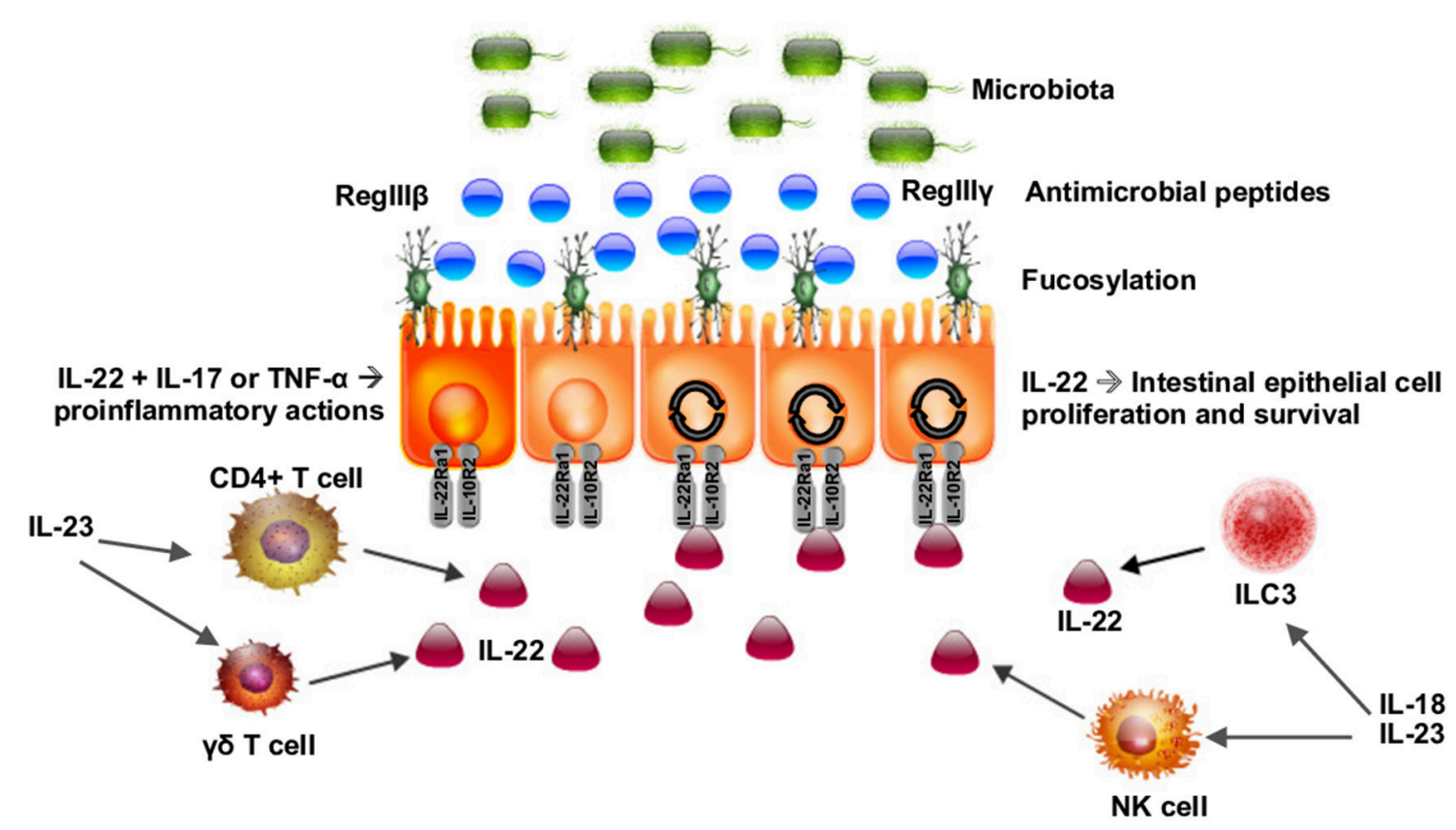

FIGURE 1 | Schematic of IL-22 as a key regulator of the interaction of the microbiota with the intestinal epithelium. IL-22 is produced by CD4+ and $\gamma \delta$ T cells as well as type 3 innate lymphoid cells (ILC3s). IL-22 acts on intestinal epithelial cells inducing fucosylation and the release of antimicrobial peptides (AMPs), regulating the microbiota, and maintaining gut barrier homeostasis. IL-22 can act synergistically with IL-17 and TNF- $\alpha$ to activate a proinflammatory response to certain pathogens.

has the opposite effect, increasing mortality and inflammation in target tissues (Hanash et al., 2012; Couturier et al., 2013; Zhao et al., 2013, 2014). Furthermore, recipient-derived IL-22 is produced by ILCs, while donor-derived IL-22 is produced by donor $\mathrm{T}$ cells (Hanash et al., 2012). It is thought that the opposing effects may be due to several different mechanisms including the target cells and distinct localizations of donor $\mathrm{T}$ cells and recipient ILCs in tissues (Hanash et al., 2012). The potential benefits of IL-22 in GVHD may also be limited since recipient IL- $22^{+}$ILCs can be removed by alloreactive donor T cells (Hanash et al., 2012). There is a clinical trial in progress to assess the safety and tolerability of recombinant human IL-22 IgG2-Fc (F-652) in combination with systemic corticosteroids for the treatment of acute gastrointestinal GVHD in hematopoietic stem cell transplantation recipients (ClinicalTrials.gov identifier NCT02406651; Generon Corporation Memorial and Sloan Kettering Cancer, 2016). It has further been noted that there may be a parallel between IL-22 deficiency in GVHD and the condition autoimmune polyendocrinopathy-candidiasisectodermal dystrophy (APECED), in which antibodies have the ability to neutralize cytokines such as IL-22 (Kärner et al., 2013; Laakso et al., 2014). As IL-22 levels decrease in patients with APECED, they can develop an increased susceptibility to candida infections (Kärner et al., 2013; Laakso et al., 2014).

IL-22 stimulates the production of molecules from cells within the intestinal epithelium (Peterson and Artis, 2014). For example, molecules like Reg3 and the defensins are thought to be regulated by IL-22 (Kolls et al., 2008; Salzman and Bevins, 2013). However, Paneth cells can produce Reg3 and defensins with limited evidence that IL-22 is solely responsible for this effect (Kolls et al., 2008; Salzman and Bevins, 2013). In addition, a common pathological finding in GVHD is a decrease in the number of Paneth cells (Eriguchi et al., 2012). Therefore, further research is required to understand the role of IL-22 in the regulation and production of these molecules in order to understand pathogenesis of diseases of the GI tract such as GVHD.

\section{Maintenance of the GI Epithelial Barrier}

Cross talk between IL-22, ILC3s, and the microbiota within the intestine contributes to the regulation and maintenance of the intestinal epithelial barrier by IL-22 (Sonnenberg et al., 2012). ILC-derived IL-22 has been found to be essential for preventing systemic inflammation, specifically containing species like Alcaligenes, a genus of Gram-negative bacteria residing within the mesenteric lymph nodes and Peyer's patches (Sonnenberg et al., 2012). Mice that are deficient in IL-22 display very few epithelial tissue perturbations (Zheng et al., 2008; Sonnenberg et al., 2011b, 2012). However, when these mice are exposed to C. rodentium, they develop severe colitis (Zheng et al., 2008; Sonnenberg et al., 2011b). Studies have shown that colitis can be reversed by the introduction of IL-22 (Sonnenberg et al., 2012). In a similar study, mice deficient in ILC3s were found to also be very susceptible to DSS-induced colitis (Sawa et al., 2011). This suggests that ILC3-derived IL-22 plays a protective role in the epithelial tissue against pathogens (Sawa et al., 2011).

The study by Backert et al. (2014) on infectious colitis revealed that the activation of STAT3 in CD4+ cells is necessary for 
the expression of IL-22 to facilitate host defense against $C$. rodentium infection. Mice deficient in STAT3 in CD4+ cells mice exhibited no change in the initial course of their infection during the innate lymphoid cell-dependent phase (Backert et al., 2014). However, during the lymphocyte-dependent phase of infection, these mice displayed an augmented distribution of the bacteria as well as significant defects in the intestinal epithelial barrier (Backert et al., 2014). Specifically, the lamina propria was notably significantly deficient in IL-22-producing $\mathrm{CD} 4^{+}$ lymphocytes (Backert et al., 2014). This observation suggests that both Th17 and Th22 cells are dependent on STAT3 activation to promote the production of IL-22 (Backert et al., 2014). In mice with active STAT3, the intestinal epithelial barrier was intact and functional, successfully protecting against enteropathogenic bacteria (Backert et al., 2014). These results contribute to our understanding of the mechanisms underlying the role IL-22 in maintenance of the gastrointestinal epithelial integrity.

In bacterial infections caused by $C$. rodentium and $T$. gondii, Munoz and colleagues found that intestinal epithelial cell production of IL-18 is mediated by IL-22 in these two models of intestinal inflammation (Muñoz et al., 2015). IL-18 is required for ILCs to express IL-22, and IL-22 was shown to increase the expression of IL-18 mRNA in the gastrointestinal tissue (Muñoz et al., 2015). In IL-22-deficient mice, there was a reduction in Th1 cells promoting IL-18 expression (Muñoz et al., 2015). Specifically in C. rodentium infection, both IL-22 and IL18 together contribute to barrier defense against the infection (Muñoz et al., 2015). In T. gondii infection, IL-18 is required for IL-22 production in the ileum (Muñoz et al., 2015). This study demonstrated the mutual regulation between IL-18 and IL22 in defense against intestinal infections (Muñoz et al., 2015). These studies contribute to the understanding of the regulation of IL-22 in maintaining gastrointestinal integrity against bacterial pathogens.

In addition to bacterial pathogens, IL-22 can also assist in controlling viral infections. ILC3 production of IL-22 was found to upregulate IFN- $\lambda$ by intestinal epithelial cells and act synergistically to control rotavirus infection (Hernández et al., 2015), a common diarrheal infection in childhood. The effect of IL-22 on controlling rotavirus replication was dependent on IFN$\lambda \mathrm{R}$ signaling and STAT1 activation and independent of STAT3 (Hernández et al., 2015). These data provide evidence that IL22 may also provide effective clearance of other GI related viral illness.

\section{The Function of IL-22 in Secondary Lymphoid Tissue}

The role that IL-22 plays in secondary lymphoid tissue and mucosa-associated lymphoid tissues (MALTs) including lymph nodes, cryptopatches, isolated lymphoid follicles (ILFs), and Peyer's patches has not been fully elucidated. A study demonstrated that stimulation of Peyer's patches with IL-23 induced NKp46 + NK cells to produce IL-22 (Yoshida et al., 1999; Sun et al., 2000; Eberl and Littman, 2003; Cupedo et al., 2004; Finke, 2005; Tsuji et al., 2008). Furthermore, ILF development is dependent on LTi cells, which produce IL-17, IL-22, and LT $\alpha_{1} \beta_{2}$ (Ota et al., 2011). The study by Ota et al. demonstrated that the $\mathrm{LT} \alpha_{1} \beta_{2}$ pathway has an important role in IL-22 production during infection with $C$. rodentium (Ota et al., 2011). When the $\mathrm{LT} \alpha_{1} \beta_{2}$ pathway was blocked, colonic IL-22 expression was significantly decreased and exogenous IL-22 administration attenuated colonic damage related to $C$. rodentium infection (Ota et al., 2011). This suggests that IL-22 may be an essential contributor to the maintenance of intestinal lymphoid tissue in the presence of inflammation. Moreover, further studies revealed that the AhR drives IL-22 production, and AhR-deficient mice were not protected against $C$. rodentium infection due in part to a defect in IL-22 production in the lamina propria and Peyer's patches (Zheng et al., 2007). AhR-deficient mice were also found to have a lack of cryptopatches and mature ILFs without affecting formation of Peyer's patches (Zheng et al., 2007). Future studies are warranted to determine whether IL-22 directly or indirectly participates in the maintenance of the GI tract lymphoid tissue and host defense against pathogens in the presence of an infection.

\section{Acute Polymicrobial Sepsis}

Weber et al. investigated the role of IL-22 in polymicrobial peritonitis (Weber et al., 2007). The authors infected mice that had been administered recombinant IL-22BP in the form of an Fc 2 a fusion protein (Weber et al., 2007). Mice were treated with IL-22BP-Fc (an IL-22 antagonist; Xie et al., 2000; Dumoutier et al., 2001; Nagalakshmi et al., 2004) 4 hours before polymicrobial septic peritonitis (Weber et al., 2007). Analysis of these mice revealed that there was a significant accumulation of neutrophils and mononuclear phagocytes in conjunction with reduced bacterial load at the direct point of infection (Weber et al., 2007). Additionally, the liver and kidneys of these mice experienced increased bacterial clearance, and kidney injury was ameliorated (Weber et al., 2007). As sepsis progressed in polymicrobial peritonitis, activation of IL-22RA1 and induction of IL-22 produced a pro-inflammatory response that exacerbated the infection (Weber et al., 2007). Bacterial spread and organ failure, which are consequences of polymicrobial peritonitis, appeared to increase due to the role of IL-22 in the progression of sepsis (Weber et al., 2007). They found that both IL-22 and IL-10 were expressed in the presence of sepsis as a consequence of polymicrobial peritonitis (Weber et al., 2007). However, IL-22 was predominantly expressed in the spleen and kidneys, while IL10 was more widespread in several organs including the spleen, kidney, and liver (Weber et al., 2007). These findings suggest IL22 influences the production of cytokines and affects the ability of the tissues to provide antibacterial host defense mechanisms in the presence of acute sepsis and peritonitis (Weber et al., 2007). Accordingly, IL-22 has a significant role in acute infection. Furthermore, the IL-22BP derived from Fcy2a fusion protein can serve as an antagonist to the effects of IL-22 during acute sepsis, and suggests a potential therapeutic intervention for polymicrobial peritonitis (Weber et al., 2007).

\section{CONCLUSIONS}

In conclusion, IL-22 plays an important role in the pathogenesis of many intestinal diseases. IL-22 promotes epithelial wound 
healing and proliferation of several cell types and in various tissues. Furthermore, the studies described in this review highlight IL-22 as a potential and promising therapeutic target for many gastrointestinal diseases. Extensive research on IL22 is necessary to fully describe and explain the differences in the ability of this cytokine to provide pro- or antiinflammatory responses in particular tissues and disease states. A deeper understanding of the regulation and function of IL-22 provides a potential opportunity for the development of novel preventative or therapeutic approaches to many diseases.

\section{REFERENCES}

Alam, M. S., Maekawa, Y., Kitamura, A., Tanigaki, K., Yoshimoto, T., Kishihara, K., et al. (2010). Notch signaling drives IL-22 secretion in CD4+ T cells by stimulating the aryl hydrocarbon receptor. Proc. Natl. Acad. Sci. U.S.A. 107, 5943-5948. doi: 10.1073/pnas.0911755107

Andoh, A., Zhang, Z., Inatomi, O., Fujino, S., Deguchi, Y., Araki, Y., et al. (2005). Interleukin-22, a member of the IL-10 subfamily, induces inflammatory responses in colonic subepithelial myofibroblasts. Gastroenterology 129, 969-984. doi: 10.1053/j.gastro.2005.06.071

Backert, I., Koralov, S. B., Wirtz, S., Kitowski, V., Billmeier, U., Martini, E., et al. (2014). STAT3 activation in Th17 and Th22 cells controls IL-22-mediated epithelial host defense during infectious colitis. J. Immunol. 193, 3779-3791. doi: 10.4049/jimmunol.1303076

Basu, R., O’Quinn, D. B., Silberger, D. J., Schoeb, T. R., Fouser, L., Ouyang, W., et al. (2012). Th22 cells are an important source of IL-22 for host protection against enteropathogenic bacteria. Immunity 37, 1061-1075. doi: 10.1016/j.immuni.2012.08.024

Bauquet, A. T., Jin, H., Paterson, A. M., Mitsdoerffer, M., Ho, I. C., Sharpe, A. H., et al. (2009). The costimulatory molecule ICOS regulates the expression of cMaf and IL-21 in the development of follicular T helper cells and TH-17 cells. Nat. Immunol. 10, 167-175. doi: 10.1038/ni.1690

Bendelac, A., Savage, P. B., and Teyton, L. (2007). The biology of NKT cells. Annu. Rev. Immunol. 25, 297-336. doi: 10.1146/annurev.immunol.25.022106.141711

Benlagha, K., Wei, D. G., Veiga, J., Teyton, L., and Bendelac, A. (2005). Characterization of the early stages of thymic NKT cell development. J. Exp. Med. 202, 485-492. doi: 10.1084/jem.20050456

Bleicher, L., de Moura, P. R., Watanabe, L., Colau, D., Dumoutier, L., Renauld, J. C., et al. (2008). Crystal structure of the IL-22/IL-22R1 complex and its implications for the IL-22 signaling mechanism. FEBS Lett. 582, 2985-2992. doi: 10.1016/j.febslet.2008.07.046

Cash, H. L., Whitham, C. V., Behrendt, C. L., and Hooper, L. V. (2006). Symbiotic bacteria direct expression of an intestinal bactericidal lectin. Science 313, 1126-1130. doi: 10.1126/science.1127119

Cella, M., Fuchs, A., Vermi, W., Facchetti, F., Otero, K., Lennerz, J. K., et al. (2009). A human natural killer cell subset provides an innate source of IL-22 for mucosal immunity. Nature 457, 722-725. doi: 10.1038/nature07537

Cella, M., Miller, H., and Song, C. (2014). Beyond NK cells: the expanding universe of innate lymphoid cells. Front. Immunol. 5:282. doi: 10.3389/fimmu.2014.00282

Cella, M., Otero, K., and Colonna, M. (2010). Expansion of human NK-22 cells with IL-7, IL-2, and IL-1beta reveals intrinsic functional plasticity. Proc. Natl. Acad. Sci. U.S.A. 107, 10961-10966. doi: 10.1073/pnas.1005641107

Chen, V. L., Surana, N. K., Duan, J., and Kasper, D. L. (2013). Role of murine intestinal interleukin-1 receptor 1-expressing lymphoid tissue inducer-like cells in Salmonella infection. PLoS ONE 8:e65405. doi: 10.1371/journal.pone.0065405

Ciccia, F., Guggino, G., Rizzo, A., Ferrante, A., Raimondo, S., Giardina, A., et al. (2012). Potential involvement of IL-22 and IL-22-producing cells in the inflamed salivary glands of patients with Sjogren's syndrome. Ann. Rheum. Dis. 71, 295-301. doi: 10.1136/ard.2011.154013

\section{FUNDING}

DP is supported by R01HL122760. JK is supported by R01HL062052 and R37HL079142. MG is supported by K08DK101608 from the National Institutes of Health and the Children's Hospital of Pittsburgh of the UPMC Health System.

\section{ACKNOWLEDGMENTS}

We would like to thank Drs. Jon Piganelli and Elizabeth Novak for critically reviewing the manuscript.
Colonna, M. (2009). Interleukin-22-producing natural killer cells and lymphoid tissue inducer-like cells in mucosal immunity. Immunity 31, 15-23. doi: 10.1016/j.immuni.2009.06.008

Couturier, M., Lamarthee, B., Arbez, J., Renauld, J. C., Bossard, C., Malard, F., et al. (2013). IL-22 deficiency in donor T cells attenuates murine acute graft-versushost disease mortality while sparing the graft-versus-leukemia effect. Leukemia 27, 1527-1537. doi: 10.1038/leu.2013.39

Crellin, N. K., Trifari, S., Kaplan, C. D., Cupedo, T., and Spits, H. (2010). Human NKp44+IL-22+ cells and LTi-like cells constitute a stable RORC+ lineage distinct from conventional natural killer cells. J. Exp. Med. 207, 281-290. doi: 10.1084/jem.20091509

Cupedo, T., Crellin, N. K., Papazian, N., Rombouts, E. J., Weijer, K., Grogan, J. L., et al. (2009). Human fetal lymphoid tissue-inducer cells are interleukin 17-producing precursors to RORC+CD127+ natural killer-like cells. Nat. Immunol. 10, 66-74. doi: 10.1038/ni.1668

Cupedo, T., Jansen, W., Kraal, G., and Mebius, R. E. (2004). Induction of secondary and tertiary lymphoid structures in the skin. Immunity 21, 655-667. doi: 10.1016/j.immuni.2004.09.006

Delsing, C. E., Bleeker-Rovers, C. P., van de Veerdonk, F. L., Tol, J., van der Meer, J. W., Kullberg, B. J., et al. (2012). Association of esophageal candidiasis and squamous cell carcinoma. Med. Mycol. Case Rep. 1, 5-8. doi: 10.1016/j.mmcr.2012.02.003

Denison, M. S., and Nagy, S. R. (2003). Activation of the aryl hydrocarbon receptor by structurally diverse exogenous and endogenous chemicals. Annu. Rev. Pharmacol. Toxicol. 43, 309-334. doi: 10.1146/annurev.pharmtox.43.100901.135828

Diefenbach, A. (2012). Interleukin-22, the guardian of the intestinal stem cell niche? Immunity 37, 196-198. doi: 10.1016/j.immuni.2012.08.007

Doisne, J. M., Soulard, V., Becourt, C., Amniai, L., Henrot, P., Havenar-Daughton, C., et al. (2011). Cutting edge: crucial role of IL-1 and IL-23 in the innate IL17 response of peripheral lymph node NK1.1- invariant NKT cells to bacteria. J. Immunol. 186, 662-666. doi: 10.4049/jimmunol.1002725

Dudakov, J. A., Hanash, A. M., and van den Brink, M. R. (2015). Interleukin22: immunobiology and pathology. Annu. Rev. Immunol. 33, 747-785. doi: 10.1146/annurev-immunol-032414-112123

Duhen, T., Geiger, R., Jarrossay, D., Lanzavecchia, A., and Sallusto, F. (2009). Production of interleukin 22 but not interleukin 17 by a subset of human skin-homing memory T cells. Nat. Immunol. 10, 857-863. doi: 10.1038/ni.1767

Dumoutier, L., Lejeune, D., Colau, D., and Renauld, J. C. (2001). Cloning and characterization of IL-22 binding protein, a natural antagonist of IL-10related T cell-derived inducible factor/IL-22. J. Immunol. 166, 7090-7095. doi: 10.4049/jimmunol.166.12.7090

Dumoutier, L., Louahed, J., and Renauld, J. C. (2000a). Cloning and characterization of IL-10-related T cell-derived inducible factor (IL-TIF), a novel cytokine structurally related to IL-10 and inducible by IL-9. J. Immunol. 164, 1814-1819. doi: 10.4049/jimmunol.164.4.1814

Dumoutier, L., Van Roost, E., Ameye, G., Michaux, L., and Renauld, J. C. (2000b). IL-TIF/IL-22: genomic organization and mapping of the human and mouse genes. Genes Immun. 1, 488-494. doi: 10.1038/sj.gene.6363716

Dumoutier, L., Van Roost, E., Colau, D., and Renauld, J. C. (2000c). Human interleukin-10-related $\mathrm{T}$ cell-derived inducible factor: molecular cloning and 
functional characterization as an hepatocyte-stimulating factor. Proc. Natl. Acad. Sci. U.S.A. 97, 10144-10149. doi: 10.1073/pnas.170291697

Eberl, G., Colonna, M., Di Santo, J. P., and McKenzie, A. N. (2015). Innate lymphoid cells. Innate lymphoid cells: a new paradigm in immunology. Science 348, aaa6566. doi: 10.1126/science.aaa6566

Eberl, G., and Littman, D. R. (2003). The role of the nuclear hormone receptor RORgammat in the development of lymph nodes and Peyer's patches. Immunol. Rev. 195, 81-90. doi: 10.1034/j.1600-065X.2003.00074.x

Edelblum, K. L., Singh, G., Odenwald, M. A., Lingaraju, A., El Bissati, K., McLeod, R., et al. (2015). gammadelta intraepithelial lymphocyte migration limits transepithelial pathogen invasion and systemic disease in mice. Gastroenterology 148, 1417-1426. doi: 10.1053/j.gastro.2015.02.053

Eriguchi, Y., Takashima, S., Oka, H., Shimoji, S., Nakamura, K., Uryu, H., et al. (2012). Graft-versus-host disease disrupts intestinal microbial ecology by inhibiting Paneth cell production of alpha-defensins. Blood 120, 223-231. doi: 10.1182/blood-2011-12-401166

Esser, C., Rannug, A., and Stockinger, B. (2009). The aryl hydrocarbon receptor in immunity. Trends Immunol. 30, 447-454. doi: 10.1016/j.it.2009.06.005

Fallon, P. G., Ballantyne, S. J., Mangan, N. E., Barlow, J. L., Dasvarma, A., Hewett, D. R., et al. (2006). Identification of an interleukin (IL)-25-dependent cell population that provides IL-4, IL-5, and IL-13 at the onset of helminth expulsion. J. Exp. Med. 203, 1105-1116. doi: 10.1084/jem.20051615

Finke, D. (2005). Fate and function of lymphoid tissue inducer cells. Curr. Opin. Immunol. 17, 144-150. doi: 10.1016/j.coi.2005.01.006

Fuell, C., Kober, O. I., Hautefort, I., and Juge, N. (2015). Mice deficient in intestinal gammadelta intraepithelial lymphocytes display an altered intestinal O-glycan profile compared with wild-type littermates. Glycobiology 25, 42-54. doi: $10.1093 /$ glycob/cwu088

Gallo, R. L., and Hooper, L. V. (2012). Epithelial antimicrobial defence of the skin and intestine. Nat. Rev. Immunol. 12, 503-516. doi: 10.1038/nri3228

Generon Corporation (Shanghai) and Memorial Sloan Kettering Cancer (2016). Study of IL-22 IgG2-Fc (F-652) for Subjects With Grade II-IV Lower GI a GVHD. New York, NY.

Gladiator, A., Wangler, N., Trautwein-Weidner, K., and Leibundgut-Landmann, S. (2013). Cutting edge: IL-17-secreting innate lymphoid cells are essential for host defense against fungal infection. J. Immunol. 190, 521-525. doi: 10.4049/jimmunol.1202924

Godfrey, D. I., Stankovic, S., and Baxter, A. G. (2010). Raising the NKT cell family. Nat. Immunol. 11, 197-206. doi: 10.1038/ni.1841

Goto, Y., Obata, T., Kunisawa, J., Sato, S., Ivanov, I. I., Lamichhane, A., et al. (2014). Innate lymphoid cells regulate intestinal epithelial cell glycosylation. Science 345, 1254009. doi: 10.1126/science. 1254009

Hanash, A. M., Dudakov, J. A., Hua, G., O'Connor, M. H., Young, L. F., Singer, N. V., et al. (2012). Interleukin-22 protects intestinal stem cells from immunemediated tissue damage and regulates sensitivity to graft versus host disease. Immunity 37, 339-350. doi: 10.1016/j.immuni.2012.05.028

Hasegawa, M., Yada, S., Liu, M. Z., Kamada, N., Munoz-Planillo, R., Do, N., et al. (2014). Interleukin-22 regulates the complement system to promote resistance against pathobionts after pathogen-induced intestinal damage. Immunity 41, 620-632. doi: 10.1016/j.immuni.2014.09.010

Hepworth, M. R., Monticelli, L. A., Fung, T. C., Ziegler, C. G., Grunberg, S., Sinha, R., et al. (2013). Innate lymphoid cells regulate CD4+ T-cell responses to intestinal commensal bacteria. Nature 498, 113-117. doi: 10.1038/nature12240

Hernández, P. P., Mahlakõiv, T., Yang, I., Schwierzeck, V., Nguyen, N., Guendel, F., et al. (2015). Interferon-lambda and interleukin 22 act synergistically for the induction of interferon-stimulated genes and control of rotavirus infection. Nat. Immunol. 16, 698-707. doi: 10.1038/ni.3180

Hoyler, T., Klose, C. S., Souabni, A., Turqueti-Neves, A., Pfeifer, D., Rawlins, E. L., et al. (2012). The transcription factor GATA-3 controls cell fate and maintenance of type 2 innate lymphoid cells. Immunity 37, 634-648. doi: 10.1016/j.immuni.2012.06.020

Huber, S., Gagliani, N., Zenewicz, L. A., Huber, F. J., Bosurgi, L., Hu, B., et al. (2012). IL-22BP is regulated by the inflammasome and modulates tumorigenesis in the intestine. Nature 491, 259-263. doi: 10.1038/nature11535

Hughes, T., Becknell, B., Freud, A. G., McClory, S., Briercheck, E., Yu, J., et al. (2010). Interleukin-1beta selectively expands and sustains interleukin-22+ immature human natural killer cells in secondary lymphoid tissue. Immunity 32, 803-814. doi: 10.1016/j.immuni.2010.06.007
Hughes, T., Becknell, B., McClory, S., Briercheck, E., Freud, A. G., Zhang, X., et al. (2009). Stage 3 immature human natural killer cells found in secondary lymphoid tissue constitutively and selectively express the TH 17 cytokine interleukin-22. Blood 113, 4008-4010. doi: 10.1182/blood-2008-12-192443

Ikeuchi, H., Kuroiwa, T., Hiramatsu, N., Kaneko, Y., Hiromura, K., Ueki, K., et al. (2005). Expression of interleukin-22 in rheumatoid arthritis: potential role as a proinflammatory cytokine. Arthritis Rheum. 52, 1037-1046. doi: 10.1002/art.20965

Ivanov, I. I., Atarashi, K., Manel, N., Brodie, E. L., Shima, T., Karaoz, U., et al. (2009). Induction of intestinal Th17 cells by segmented filamentous bacteria. Cell 139, 485-498. doi: 10.1016/j.cell.2009.09.033

Jones, B. C., Logsdon, N. J., and Walter, M. R. (2008). Structure of IL22 bound to its high-affinity IL-22R1 chain. Structure 16, 1333-1344. doi: $10.1016 /$ j.str.2008.06.005

Kärner, J., Meager, A., Laan, M., Maslovskaja, J., Pihlap, M., Remm, A., et al. (2013). Anti-cytokine autoantibodies suggest pathogenetic links with autoimmune regulator deficiency in humans and mice. Clin. Exp. Immunol. 171, 263-272. doi: $10.1111 /$ cei. 12024

Kastelein, R. A., Hunter, C. A., and Cua, D. J. (2007). Discovery and biology of IL-23 and IL-27: related but functionally distinct regulators of inflammation. Аnnu. Rev. Immunol. 25, 221-242. doi: 10.1146/annurev.immunol.22.012703.104758

Kato-Kogoe, N., Nishioka, T., Kawabe, M., Kataoka, F., Yamanegi, K., Yamada, N., et al. (2012). The promotional effect of IL-22 on mineralization activity of periodontal ligament cells. Cytokine 59, 41-48. doi: 10.1016/j.cyto.2012.03.024

Kim, C. J., Nazli, A., Rojas, O. L., Chege, D., Alidina, Z., Huibner, S., et al. (2012). A role for mucosal IL-22 production and Th22 cells in HIV-associated mucosal immunopathogenesis. Mucosal Immunol. 5, 670-680. doi: 10.1038/mi.2012.72

Klose, C. S., Flach, M., Möhle, L., Rogell, L., Hoyler, T., Ebert, K., et al. (2014). Differentiation of type 1 ILCs from a common progenitor to all helper-like innate lymphoid cell lineages. Cell 157, 340-356. doi: 10.1016/j.cell.2014.03.030

Kolls, J. K., McCray, P. B. Jr., and Chan, Y. R. (2008). Cytokine-mediated regulation of antimicrobial proteins. Nat. Rev. Immunol. 8, 829-835. doi: 10.1038/nri2433

Korn, L. L., Thomas, H. L., Hubbeling, H. G., Spencer, S. P., Sinha, R., Simkins, H. M., et al. (2014). Conventional CD4+ T cells regulate IL-22producing intestinal innate lymphoid cells. Mucosal Immunol. 7, 1045-1057. doi: $10.1038 / \mathrm{mi} .2013 .121$

Kotenko, S. V., Izotova, L. S., Mirochnitchenko, O. V., Esterova, E., Dickensheets, H., Donnelly, R. P., et al. (2001). Identification, cloning, and characterization of a novel soluble receptor that binds IL-22 and neutralizes its activity. J. Immunol. 166, 7096-7103. doi: 10.4049/jimmunol.166.12.7096

Kotenko, S. V., Krause, C. D., Izotova, L. S., Pollack, B. P., Wu, W., and Pestka, S. (1997). Identification and functional characterization of a second chain of the interleukin-10 receptor complex. $E M B O ~ J .16,5894-5903$. doi: 10.1093/emboj/16.19.5894

Laakso, S. M., Kekäläinen, E., Heikkilä, N., Mannerström, H., Kisand, K., Peterson, P., et al. (2014). In vivo analysis of helper $\mathrm{T}$ cell responses in patients with autoimmune polyendocrinopathy - candidiasis - ectodermal dystrophy provides evidence in support of an IL-22 defect. Autoimmunity 47, 556-562. doi: $10.3109 / 08916934.2014 .929666$

Langrish, C. L., McKenzie, B. S., Wilson, N. J., de Waal Malefyt, R., Kastelein, R. A., and Cua, D. J. (2004). IL-12 and IL-23: master regulators of innate and adaptive immunity. Immunol. Rev. 202, 96-105. doi: 10.1111/j.0105-2896.2004.00214.x

Lee, J. S., Cella, M., McDonald, K. G., Garlanda, C., Kennedy, G. D., Nukaya, M., et al. (2012). AHR drives the development of gut ILC22 cells and postnatal lymphoid tissues via pathways dependent on and independent of Notch. Nat. Immunol. 13, 144-151. doi: 10.1038/ni.2187

Lee, Y., Kumagai, Y., Jang, M. S., Kim, J. H., Yang, B. G., Lee, E. J., et al. (2013). Intestinal Lin- c-Kit+ NKp46- CD4- population strongly produces IL-22 upon IL-1beta stimulation. J. Immunol. 190, 5296-5305. doi: 10.4049/jimmunol.1201452

Lee, Y. S., Yang, H., Yang, J. Y., Kim, Y., Lee, S. H., Kim, J. H., et al. (2015). Interleukin-1 (IL-1) signaling in intestinal stromal cells controls KC/ CXCL1 secretion, which correlates with recruitment of IL-22- secreting neutrophils at early stages of Citrobacter rodentium infection. Infect. Immun. 83, 3257-3267. doi: 10.1128/IAI.00670-15

Lejeune, D., Dumoutier, L., Constantinescu, S., Kruijer, W., Schuringa, J. J., and Renauld, J. C. (2002). Interleukin-22 (IL-22) activates the JAK/STAT, ERK, JNK, 
and p38 MAP kinase pathways in a rat hepatoma cell line. Pathways that are shared with and distinct from IL-10. J. Biol. Chem. 277, 33676-33682. doi: 10.1074/jbc.M204204200

Li, J., Tomkinson, K. N., Tan, X. Y., Wu, P., Yan, G., Spaulding, V., et al. (2004). Temporal associations between interleukin 22 and the extracellular domains of IL-22R and IL-10R2. Int. Immunopharmacol. 4, 693-708. doi: 10.1016/j.intimp.2004.01.010

Liang, S. C., Tan, X. Y., Luxenberg, D. P., Karim, R., Dunussi-Joannopoulos, K., Collins, M., et al. (2006). Interleukin (IL)-22 and IL-17 are coexpressed by Th17 cells and cooperatively enhance expression of antimicrobial peptides. J. Exp. Med. 203, 2271-2279. doi: 10.1084/jem.20061308

Littman, D. R., and Rudensky, A. Y. (2010). Th17 and regulatory T cells in mediating and restraining inflammation. Cell 140, 845-858. doi: 10.1016/j.cell.2010.02.021

Logsdon, N. J., Jones, B. C., Allman, J. C., Izotova, L., Schwartz, B., Pestka, S., et al. (2004). The IL-10R2 binding hot spot on IL-22 is located on the N-terminal helix and is dependent on N-linked glycosylation. J. Mol. Biol. 342, 503-514. doi: 10.1016/j.jmb.2004.07.069

Logsdon, N. J., Jones, B. C., Josephson, K., Cook, J., and Walter, M. R. (2002). Comparison of interleukin-22 and interleukin-10 soluble receptor complexes. J. Interferon Cytokine Res. 22, 1099-1112. doi: 10.1089/10799900260442520

Lowe, M. M., Mold, J. E., Kanwar, B., Huang, Y., Louie, A., Pollastri, M. P., et al. (2014). Identification of cinnabarinic acid as a novel endogenous aryl hydrocarbon receptor ligand that drives IL-22 production. PLoS ONE 9:e87877. doi: 10.1371/journal.pone.0087877

Luci, C., Reynders, A., Ivanov, I. I., Cognet, C., Chiche, L., Chasson, L., et al. (2009). Influence of the transcription factor RORgammat on the development of NKp46+ cell populations in gut and skin. Nat. Immunol. 10, 75-82. doi: 10.1038/ni.1681

Mabuchi, T., Takekoshi, T., and Hwang, S. T. (2011). Epidermal CCR6+ gammadelta $\mathrm{T}$ cells are major producers of IL-22 and IL-17 in a murine model of psoriasiform dermatitis. J. Immunol. 187, 5026-5031. doi: 10.4049/jimmunol.1101817

Macdonald, T. T., and Monteleone, G. (2005). Immunity, inflammation, and allergy in the gut. Science 307, 1920-1925. doi: 10.1126/science.1106442

Macho-Fernandez, E., Koroleva, E. P., Spencer, C. M., Tighe, M., Torrado, E., Cooper, A. M., et al. (2015). Lymphotoxin beta receptor signaling limits mucosal damage through driving IL-23 production by epithelial cells. Mucosal Immunol. 8, 403-413. doi: 10.1038/mi.2014.78

Mangan, P. R., Harrington, L. E., O'Quinn, D. B., Helms, W. S., Bullard, D. C., Elson, C. O., et al. (2006). Transforming growth factor-beta induces development of the $\mathrm{T}(\mathrm{H}) 17$ lineage. Nature 441, 231-234. doi: 10.1038 /nature 04754

Mann, E. R., Bernardo, D., Ng, S. C., Rigby, R. J., Al-Hassi, H. O., Landy, J., et al. (2014). Human gut dendritic cells drive aberrant gut-specific t-cell responses in ulcerative colitis, characterized by increased IL-4 production and loss of IL-22 and IFNgamma. Inflamm. Bowel Dis. 20, 2299-2307. doi: 10.1097/MIB.0000000000000223

Martin, B., Hirota, K., Cua, D. J., Stockinger, B., and Veldhoen, M. (2009). Interleukin-17-producing gammadelta $\mathrm{T}$ cells selectively expand in response to pathogen products and environmental signals. Immunity 31, 321-330. doi: 10.1016/j.immuni.2009.06.020

Martin, J. C., Bériou, G., Heslan, M., Bossard, C., Jarry, A., Abidi, A., et al. (2015). IL-22BP is produced by eosinophils in human gut and blocks IL-22 protective actions during colitis. Mucosal Immunol. doi: 10.1038/mi.2015.83. [Epub ahead of print].

Martin, J. C., Bériou, G., Heslan, M., Chauvin, C., Utriainen, L., Aumeunier, A., et al. (2014). Interleukin-22 binding protein (IL-22BP) is constitutively expressed by a subset of conventional dendritic cells and is strongly induced by retinoic acid. Mucosal Immunol. 7, 101-113. doi: 10.1038/mi.2013.28

McMillan, B. J., and Bradfield, C. A. (2007). The aryl hydrocarbon receptor is activated by modified low-density lipoprotein. Proc. Natl. Acad. Sci. U.S.A. 104, 1412-1417. doi: 10.1073/pnas.0607296104

Mead, P. S., and Griffin, P. M. (1998). Escherichia coli O157:H7. Lancet 352, 1207-1212. doi: 10.1016/S0140-6736(98)01267-7

Mebius, R. E., Miyamoto, T., Christensen, J., Domen, J., Cupedo, T., Weissman, I. L., et al. (2001). The fetal liver counterpart of adult common lymphoid progenitors gives rise to all lymphoid lineages,
CD45+CD4+CD3- cells, as well as macrophages. J. Immunol. 166, 6593-6601. doi: 10.4049/jimmunol.166.11.6593

Mielke, L. A., Jones, S. A., Raverdeau, M., Higgs, R., Stefanska, A., Groom, J. R., et al. (2013). Retinoic acid expression associates with enhanced IL-22 production by gammadelta $\mathrm{T}$ cells and innate lymphoid cells and attenuation of intestinal inflammation. J. Exp. Med. 210, 1117-1124. doi: 10.1084/jem.20121588

Monteiro, M., Almeida, C. F., Agua-Doce, A., and Graca, L. (2013). Induced IL-17-producing invariant NKT cells require activation in presence of TGF-beta and IL-1beta. J. Immunol. 190, 805-811. doi: 10.4049/jimmunol. 1201010

Monteleone, I., Rizzo, A., Sarra, M., Sica, G., Sileri, P., Biancone, L., et al. (2011). Aryl hydrocarbon receptor-induced signals up-regulate IL-22 production and inhibit inflammation in the gastrointestinal tract. Gastroenterology 141, 237-248. doi: 10.1053/j.gastro.2011.04.007

Moreira-Teixeira, L., Resende, M., Coffre, M., Devergne, O., Herbeuval, J. P., Hermine, O., et al. (2011). Proinflammatory environment dictates the IL-17producing capacity of human invariant NKT cells. J. Immunol. 186, 5758-5765. doi: 10.4049/jimmunol.1003043

Morishima, N., Mizoguchi, I., Takeda, K., Mizuguchi, J., and Yoshimoto, T. (2009). TGF-beta is necessary for induction of IL-23R and Th17 differentiation by IL-6 and IL-23. Biochem. Biophys. Res. Commun. 386, 105-110. doi: 10.1016/j.bbrc.2009.05.140

Munneke, J. M., Björklund, A. T., Mjösberg, J. M., Garming-Legert, K., Bernink, J. H., Blom, B., et al. (2014). Activated innate lymphoid cells are associated with a reduced susceptibility to graft-versus-host disease. Blood 124, 812-821. doi: 10.1182/blood-2013-11-536888

Muñoz, M., Eidenschenk, C., Ota, N., Wong, K., Lohmann, U., Kühl, A. A., et al. (2015). Interleukin-22 induces interleukin-18 expression from epithelial cells during intestinal infection. Immunity 42, 321-331. doi: 10.1016/j.immuni.2015.01.011

Murano, T., Okamoto, R., Ito, G., Nakata, T., Hibiya, S., Shimizu, H., et al. (2014) Hes1 promotes the IL-22-mediated antimicrobial response by enhancing STAT3-dependent transcription in human intestinal epithelial cells. Biochem. Biophys. Res. Commun. 443, 840-846. doi: 10.1016/j.bbrc.2013.12.061

Nagalakshmi, M. L., Rascle, A., Zurawski, S., Menon, S., and de Waal Malefyt, R. (2004). Interleukin-22 activates STAT3 and induces IL-10 by colon epithelial cells. Int. Immunopharmacol. 4, 679-691. doi: 10.1016/j.intimp.2004. 01.008

Naher, L., Kiyoshima, T., Kobayashi, I., Wada, H., Nagata, K., Fujiwara, H., et al. (2012). STAT3 signal transduction through interleukin-22 in oral squamous cell carcinoma. Int. J. Oncol. 41, 1577-1586. doi: 10.3892/ijo.2012.1594

Nguyen, L. P., and Bradfield, C. A. (2008). The search for endogenous activators of the aryl hydrocarbon receptor. Chem. Res. Toxicol. 21, 102-116. doi: 10.1021/tx7001965

Nurieva, R., Yang, X. O., Martinez, G., Zhang, Y., Panopoulos, A. D., Ma, L., et al. (2007). Essential autocrine regulation by IL-21 in the generation of inflammatory T cells. Nature 448, 480-483. doi: 10.1038/nature05969

Oesch-Bartlomowicz, B., Huelster, A., Wiss, O., Antoniou-Lipfert, P., Dietrich, C., Arand, M., et al. (2005). Aryl hydrocarbon receptor activation by cAMP vs. dioxin: divergent signaling pathways. Proc. Natl. Acad. Sci. U.S.A. 102, 9218-9223. doi: 10.1073/pnas.0503488102

Ota, N., Wong, K., Valdez, P. A., Zheng, Y., Crellin, N. K., Diehl, L., et al. (2011). IL22 bridges the lymphotoxin pathway with the maintenance of colonic lymphoid structures during infection with Citrobacter rodentium. Nat. Immunol. 12, 941-948. doi: 10.1038/ni.2089

Ouyang, W., Rutz, S., Crellin, N. K., Valdez, P. A., and Hymowitz, S. G. (2011). Regulation and functions of the IL-10 family of cytokines in inflammation and disease. Annu. Rev. Immunol. 29, 71-109. doi: 10.1146/annurev-immunol031210-101312

Pacheco, A. R., Curtis, M. M., Ritchie, J. M., Munera, D., Waldor, M. K., Moreira, C. G., et al. (2012). Fucose sensing regulates bacterial intestinal colonization. Nature 492, 113-117. doi: 10.1038/nature11623

Paget, C., Ivanov, S., Fontaine, J., Renneson, J., Blanc, F., Pichavant, M., et al. (2012). Interleukin-22 is produced by invariant natural killer $\mathrm{T}$ lymphocytes during influenza A virus infection: potential role in protection against lung epithelial damages. J. Biol. Chem. 287, 8816-8829. doi: 10.1074/jbc.M111.304758 
Pan, H. F., Li, X. P., Zheng, S. G., and Ye, D. Q. (2013). Emerging role of interleukin-22 in autoimmune diseases. Cytokine Growth Factor Rev. 24, 51-57. doi: 10.1016/j.cytogfr.2012.07.002

Paulos, C. M., Carpenito, C., Plesa, G., Suhoski, M. M., Varela-Rohena, A., Golovina, T. N., et al. (2010). The inducible costimulator (ICOS) is critical for the development of human T(H)17 cells. Sci. Transl. Med. 2, 55ra78. doi: 10.1126/scitranslmed.3000448

Penel-Sotirakis, K., Simonazzi, E., Péguet-Navarro, J., and Rozières, A. (2012). Differential capacity of human skin dendritic cells to polarize CD4+ T cells into IL-17, IL-21 and IL-22 producing cells. PLoS ONE 7:e45680. doi: 10.1371/journal.pone.0045680

Peschon, J. J., Morrissey, P. J., Grabstein, K. H., Ramsdell, F. J., Maraskovsky, E., Gliniak, B. C., et al. (1994). Early lymphocyte expansion is severely impaired in interleukin 7 receptor-deficient mice. J. Exp. Med. 180, 1955-1960. doi: 10.1084/jem.180.5.1955

Peterson, L. W., and Artis, D. (2014). Intestinal epithelial cells: regulators of barrier function and immune homeostasis. Nat. Rev. Immunol. 14, 141-153. doi: $10.1038 /$ nri3608

Pham, T. A., Clare, S., Goulding, D., Arasteh, J. M., Stares, M. D., Browne, H. P., et al. (2014). Epithelial IL-22RA1-mediated fucosylation promotes intestinal colonization resistance to an opportunistic pathogen. Cell Host Microbe 16, 504-516. doi: 10.1016/j.chom.2014.08.017

Pickard, J. M., Maurice, C. F., Kinnebrew, M. A., Abt, M. C., Schenten, D., Golovkina, T. V., et al. (2014). Rapid fucosylation of intestinal epithelium sustains host-commensal symbiosis in sickness. Nature 514, 638-641. doi: $10.1038 /$ nature 13823

Pickert, G., Neufert, C., Leppkes, M., Zheng, Y., Wittkopf, N., Warntjen, M., et al. (2009). STAT3 links IL-22 signaling in intestinal epithelial cells to mucosal wound healing. J. Exp. Med. 206, 1465-1472. doi: 10.1084/jem.20082683

Possot, C., Schmutz, S., Chea, S., Boucontet, L., Louise, A., Cumano, A., et al. (2011). Notch signaling is necessary for adult, but not fetal, development of RORgammat(+) innate lymphoid cells. Nat. Immunol. 12, 949-958. doi: 10.1038/ni.2105

Puga, A., Ma, C., and Marlowe, J. L. (2009). The aryl hydrocarbon receptor crosstalks with multiple signal transduction pathways. Biochem. Pharmacol. 77, 713-722. doi: 10.1016/j.bcp.2008.08.031

Qiu, J., Guo, X., Chen, Z. M., He, L., Sonnenberg, G. F., Artis, D., et al. (2013). Group 3 innate lymphoid cells inhibit T-cell-mediated intestinal inflammation through aryl hydrocarbon receptor signaling and regulation of microflora. Immunity 39, 386-399. doi: 10.1016/j.immuni.2013.08.002

Qiu, J., Heller, J. J., Guo, X., Chen, Z. M., Fish, K., Fu, Y. X., et al. (2012). The aryl hydrocarbon receptor regulates gut immunity through modulation of innate lymphoid cells. Immunity 36, 92-104. doi: 10.1016/j.immuni.2011.11.011

Rachitskaya, A. V., Hansen, A. M., Horai, R., Li, Z., Villasmil, R., Luger, D., et al. (2008). Cutting edge: NKT cells constitutively express IL23 receptor and RORgammat and rapidly produce IL-17 upon receptor ligation in an IL-6-independent fashion. J. Immunol. 180, 5167-5171. doi: 10.4049/jimmunol.180.8.5167

Raifer, H., Mahiny, A. J., Bollig, N., Petermann, F., Hellhund, A., Kellner, K., et al. (2012). Unlike alphabeta T cells, gammadelta T cells, LTi cells and NKT cells do not require IRF4 for the production of IL-17A and IL-22. Eur. J. Immunol. 42, 3189-3201. doi: 10.1002/eji.201142155

Rutz, S., Noubade, R., Eidenschenk, C., Ota, N., Zeng, W., Zheng, Y., et al. (2011). Transcription factor c-Maf mediates the TGF-beta-dependent suppression of IL-22 production in $\mathrm{T}(\mathrm{H}) 17$ cells. Nat. Immunol. 12, 1238-1245. doi: 10.1038/ni.2134

Rutz, S., Wang, X., and Ouyang, W. (2014). The IL-20 subfamily of cytokinesfrom host defence to tissue homeostasis. Nat. Rev. Immunol. 14, 783-795. doi: $10.1038 /$ nri3766

Sabat, R., Ouyang, W., and Wolk, K. (2014). Therapeutic opportunities of the IL-22-IL-22R1 system. Nat. Rev. Drug Discov. 13, 21-38. doi: 10.1038/nrd4176

Salzman, N. H., and Bevins, C. L. (2013). Dysbiosis-a consequence of Paneth cell dysfunction. Semin. Immunol. 25, 334-341. doi: 10.1016/j.smim.2013.09.006

Sanos, S. L., Bui, V. L., Mortha, A., Oberle, K., Heners, C., Johner, C., et al. (2009). RORgammat and commensal microflora are required for the differentiation of mucosal interleukin 22-producing NKp46+ cells. Nat. Immunol. 10, 83-91. doi: 10.1038/ni.1684
Sanos, S. L., Vonarbourg, C., Mortha, A., and Diefenbach, A. (2011). Control of epithelial cell function by interleukin-22-producing RORgammat+ innate lymphoid cells. Immunology 132, 453-465. doi: 10.1111/j.13652567.2011.03410.x

Satoh-Takayama, N., Vosshenrich, C. A., Lesjean-Pottier, S., Sawa, S., Lochner, M., Rattis, F., et al. (2008). Microbial flora drives interleukin 22 production in intestinal NKp46+ cells that provide innate mucosal immune defense. Immunity 29, 958-970. doi: 10.1016/j.immuni.2008.11.001

Sawa, S., Lochner, M., Satoh-Takayama, N., Dulauroy, S., Bérard, M., Kleinschek, M., et al. (2011). RORgammat+ innate lymphoid cells regulate intestinal homeostasis by integrating negative signals from the symbiotic microbiota. Nat. Immunol. 12, 320-326. doi: 10.1038/ni.2002

Schmechel, S., Konrad, A., Diegelmann, J., Glas, J., Wetzke, M., Paschos, E., et al. (2008). Linking genetic susceptibility to Crohn's disease with Th17 cell function: IL-22 serum levels are increased in Crohn's disease and correlate with disease activity and IL23R genotype status. Inflamm. Bowel Dis. 14, 204-212. doi: 10.1002/ibd.20315

Sekikawa, A., Fukui, H., Suzuki, K., Karibe, T., Fujii, S., Ichikawa, K., et al. (2010). Involvement of the IL-22/REG Ialpha axis in ulcerative colitis. Lab. Invest. 90, 496-505. doi: 10.1038/labinvest.2009.147

Sims, J. E., and Smith, D. E. (2010). The IL-1 family: regulators of immunity. Nat. Rev. Immunol. 10, 89-102. doi: 10.1038/nri2691

Sonnenberg, G. F., Fouser, L. A., and Artis, D. (2011a). Border patrol: regulation of immunity, inflammation and tissue homeostasis at barrier surfaces by IL-22. Nat. Immunol. 12, 383-390. doi: 10.1038/ni.2025

Sonnenberg, G. F., Monticelli, L. A., Alenghat, T., Fung, T. C., Hutnick, N. A., Kunisawa, J., et al. (2012). Innate lymphoid cells promote anatomical containment of lymphoid-resident commensal bacteria. Science 336, 1321-1325. doi: 10.1126/science.1222551

Sonnenberg, G. F., Monticelli, L. A., Elloso, M. M., Fouser, L. A., and Artis, D. (2011b). CD4(+) lymphoid tissue-inducer cells promote innate immunity in the gut. Immunity 34, 122-134. doi: 10.1016/j.immuni.2010.12.009

Souza, J. M., Matias, B. F., Rodrigues, C. M., Murta, E. F., and Michelin, M. A. (2013). IL-17 and IL-22 serum cytokine levels in patients with squamous intraepithelial lesion and invasive cervical carcinoma. Eur. J. Gynaecol. Oncol. 34, 466-468.

Spits, H., Artis, D., Colonna, M., Diefenbach, A., Di Santo, J. P., Eberl, G., et al. (2013). Innate lymphoid cells-a proposal for uniform nomenclature. Nat. Rev. Immunol. 13, 145-149. doi: 10.1038/nri3365

Spits, H., and Cupedo, T. (2012). Innate lymphoid cells: emerging insights in development, lineage relationships, and function. Annu. Rev. Immunol. 30, 647-675. doi: 10.1146/annurev-immunol-020711-075053

Stelter, C., Käppeli, R., König, C., Krah, A., Hardt, W. D., Stecher, B., et al. (2011). Salmonella-induced mucosal lectin RegIIIbeta kills competing gut microbiota. PLoS ONE 6:e20749. doi: 10.1371/journal.pone.0020749

Sugimoto, K., Ogawa, A., Mizoguchi, E., Shimomura, Y., Andoh, A., Bhan, A. K., et al. (2008). IL-22 ameliorates intestinal inflammation in a mouse model of ulcerative colitis. J. Clin. Invest. 118, 534-544. doi: 10.1172/jci33194

Sun, Z., Unutmaz, D., Zou, Y. R., Sunshine, M. J., Pierani, A., BrennerMorton, S., et al. (2000). Requirement for RORgamma in thymocyte survival and lymphoid organ development. Science 288, 2369-2373. doi: 10.1126/science.288.5475.2369

Sutton, C. E., Lalor, S. J., Sweeney, C. M., Brereton, C. F., Lavelle, E. C., and Mills, K. H. (2009). Interleukin-1 and IL-23 induce innate IL-17 production from gammadelta $\mathrm{T}$ cells, amplifying Th17 responses and autoimmunity. Immunity 31, 331-341. doi: 10.1016/j.immuni.2009.08.001

Takahashi, A., Wada, A., Ogushi, K., Maeda, K., Kawahara, T., Mawatari, K., et al. (2001). Production of beta-defensin-2 by human colonic epithelial cells induced by Salmonella enteritidis flagella filament structural protein. FEBS Lett. 508, 484-488. doi: 10.1016/S0014-5793(01)03088-5

Tortola, L., Rosenwald, E., Abel, B., Blumberg, H., Schäfer, M., Coyle, A. J., et al. (2012). Psoriasiform dermatitis is driven by IL-36-mediated DC-keratinocyte crosstalk. J. Clin. Invest. 122, 3965-3976. doi: 10.1172/JCI63451

Trifari, S., Kaplan, C. D., Tran, E. H., Crellin, N. K., and Spits, H. (2009). Identification of a human helper $\mathrm{T}$ cell population that has abundant production of interleukin 22 and is distinct from $\mathrm{T}(\mathrm{H})-17, \mathrm{~T}(\mathrm{H}) 1$ and $\mathrm{T}(\mathrm{H}) 2$ cells. Nat. Immunol. 10, 864-871. doi: 10.1038/ni.1770 
Tsuji, M., Suzuki, K., Kitamura, H., Maruya, M., Kinoshita, K., Ivanov, I. I., et al. (2008). Requirement for lymphoid tissue-inducer cells in isolated follicle formation and $\mathrm{T}$ cell-independent immunoglobulin A generation in the gut. Immunity 29, 261-271. doi: 10.1016/j.immuni.2008.05.014

Tsuji, N., Fukuda, K., Nagata, Y., Okada, H., Haga, A., Hatakeyama, S., et al. (2014). The activation mechanism of the aryl hydrocarbon receptor (AhR) by molecular chaperone HSP90. FEBS Open Bio 4, 796-803. doi: 10.1016/j.fob.2014.09.003

Tumanov, A. V., Koroleva, E. P., Guo, X., Wang, Y., Kruglov, A., Nedospasov, S., et al. (2011). Lymphotoxin controls the IL-22 protection pathway in gut innate lymphoid cells during mucosal pathogen challenge. Cell Host Microbe 10, 44-53. doi: 10.1016/j.chom.2011.06.002

Vaishnava, S., Yamamoto, M., Severson, K. M., Ruhn, K. A., Yu, X., Koren, O., et al. (2011). The antibacterial lectin RegIIIgamma promotes the spatial segregation of microbiota and host in the intestine. Science 334, 255-258. doi: 10.1126/science. 1209791

van de Veerdonk, F. L., Stoeckman, A. K., Wu, G., Boeckermann, A. N., Azam, T., Netea, M. G., et al. (2012). IL-38 binds to the IL-36 receptor and has biological effects on immune cells similar to IL-36 receptor antagonist. Proc. Natl. Acad. Sci. U.S.A. 109, 3001-3005. doi: 10.1073/pnas.1121534109

Veldhoen, M., Hirota, K., Westendorf, A. M., Buer, J., Dumoutier, L., Renauld, J. C., et al. (2008). The aryl hydrocarbon receptor links TH17-cellmediated autoimmunity to environmental toxins. Nature 453, 106-109. doi: 10.1038 /nature06881

Volpe, E., Touzot, M., Servant, N., Marloie-Provost, M. A., Hupé, P., Barillot, E., et al. (2009). Multiparametric analysis of cytokine-driven human Th17 differentiation reveals a differential regulation of IL-17 and IL-22 production. Blood 114, 3610-3614. doi: 10.1182/blood-2009-05-223768

Vonarbourg, C., Mortha, A., Bui, V. L., Hernandez, P. P., Kiss, E. A., Hoyler, T., et al. (2010). Regulated expression of nuclear receptor RORgammat confers distinct functional fates to NK cell receptor-expressing RORgammat $(+)$ innate lymphocytes. Immunity 33, 736-751. doi: 10.1016/j.immuni.2010.10.017

von Freeden-Jeffry, U., Vieira, P., Lucian, L. A., McNeil, T., Burdach, S. E., and Murray, R. (1995). Lymphopenia in interleukin (IL)-7 gene-deleted mice identifies IL-7 as a nonredundant cytokine. J. Exp. Med. 181, 1519-1526. doi: 10.1084/jem.181.4.1519

Weber, G. F., Schlautkötter, S., Kaiser-Moore, S., Altmayr, F., Holzmann, B., and Weighardt, H. (2007). Inhibition of interleukin-22 attenuates bacterial load and organ failure during acute polymicrobial sepsis. Infect. Immun. 75, 1690-1697. doi: 10.1128/IAI.01564-06

Weiss, B., Wolk, K., Grünberg, B. H., Volk, H. D., Sterry, W., Asadullah, K., et al. (2004). Cloning of murine IL-22 receptor alpha 2 and comparison with its human counterpart. Genes Immun. 5, 330-336. doi: 10.1038/sj.gene.6364104

Witte, E., Witte, K., Warszawska, K., Sabat, R., and Wolk, K. (2010). Interleukin22: a cytokine produced by T, NK and NKT cell subsets, with importance in the innate immune defense and tissue protection. Cytokine Growth Factor Rev. 21, 365-379. doi: 10.1016/j.cytogfr.2010.08.002

Wolk, K., Kunz, S., Witte, E., Friedrich, M., Asadullah, K., and Sabat, R. (2004). IL-22 increases the innate immunity of tissues. Immunity 21, 241-254. doi: 10.1016/j.immuni.2004.07.007

Wolk, K., Witte, E., Hoffmann, U., Doecke, W. D., Endesfelder, S., Asadullah, K., et al. (2007). IL-22 induces lipopolysaccharide-binding protein in hepatocytes: a potential systemic role of IL-22 in Crohn's disease. J. Immunol. 178, 5973-5981. doi: 10.4049/jimmunol.178.9.5973

Wolk, K., Witte, E., Wallace, E., Döcke, W. D., Kunz, S., Asadullah, K., et al. (2006). IL-22 regulates the expression of genes responsible for antimicrobial defense, cellular differentiation, and mobility in keratinocytes: a potential role in psoriasis. Eur. J. Immunol. 36, 1309-1323. doi: 10.1002/eji.200535503

Wu, P. W., Li, J., Kodangattil, S. R., Luxenberg, D. P., Bennett, F., Martino, M., et al. (2008). IL-22R, IL-10R2, and IL-22BP binding sites are topologically juxtaposed on adjacent and overlapping surfaces of IL-22. J. Mol. Biol. 382, 1168-1183. doi: 10.1016/j.jmb.2008.07.046

Xie, M. H., Aggarwal, S., Ho, W. H., Foster, J., Zhang, Z., Stinson, J., et al. (2000). Interleukin (IL)-22, a novel human cytokine that signals through the interferon receptor-related proteins CRF2-4 and IL-22R. J. Biol. Chem. 275, 31335-31339. doi: 10.1074/jbc.M005304200

Yoon, S. I., Jones, B. C., Logsdon, N. J., Harris, B. D., Deshpande, A., Radaeva, S., et al. (2010). Structure and mechanism of receptor sharing by the IL-10R2 common chain. Structure 18, 638-648. doi: 10.1016/j.str.2010.02.009

Yoshida, H., Honda, K., Shinkura, R., Adachi, S., Nishikawa, S., Maki, K., et al. (1999). IL-7 receptor alpha+ CD3(-) cells in the embryonic intestine induces the organizing center of Peyer's patches. Int. Immunol. 11, 643-655. doi: 10.1093/intimm/11.5.643

Zelante, T., Iannitti, R. G., Cunha, C., De Luca, A., Giovannini, G., Pieraccini, G., et al. (2013). Tryptophan catabolites from microbiota engage aryl hydrocarbon receptor and balance mucosal reactivity via interleukin-22. Immunity 39, 372-385. doi: 10.1016/j.immuni.2013.08.003

Zhang, N., Pan, H. F., and Ye, D. Q. (2011). Th22 in inflammatory and autoimmune disease: prospects for therapeutic intervention. Mol. Cell. Biochem. 353, 41-46. doi: 10.1007/s11010-011-0772-y

Zhao, K., Zhao, D., Huang, D., Song, X., Chen, C., Pan, B., et al. (2013). The identification and characteristics of IL-22-producing $\mathrm{T}$ cells in acute graft-versus-host disease following allogeneic bone marrow transplantation. Immunobiology 218, 1505-1513. doi: 10.1016/j.imbio.2013.05.005

Zhao, K., Zhao, D., Huang, D., Yin, L., Chen, C., Pan, B., et al. (2014). Interleukin22 aggravates murine acute graft-versus-host disease by expanding effector $\mathrm{T}$ cell and reducing regulatory T cell. J. Interferon Cytokine Res. 34, 707-715. doi: 10.1089/jir.2013.0099

Zheng, Y., Danilenko, D. M., Valdez, P., Kasman, I., Eastham-Anderson, J., Wu, J., et al. (2007). Interleukin-22, a T(H)17 cytokine, mediates IL-23-induced dermal inflammation and acanthosis. Nature 445, 648-651. doi: 10.1038/nature05505

Zheng, Y., Valdez, P. A., Danilenko, D. M., Hu, Y., Sa, S. M., Gong, Q., et al. (2008). Interleukin-22 mediates early host defense against attaching and effacing bacterial pathogens. Nat. Med. 14, 282-289. doi: 10.1038/nm1720

Zhou, L., Ivanov, I. I., Spolski, R., Min, R., Shenderov, K., Egawa, T., et al. (2007). IL6 programs $\mathrm{T}(\mathrm{H})-17$ cell differentiation by promoting sequential engagement of the IL-21 and IL-23 pathways. Nat. Immunol. 8, 967-974. doi: 10.1038/ni1488

Zhou, L., Lopes, J. E., Chong, M. M., Ivanov, I. I., Min, R., Victora, G. D., et al. (2008). TGF-beta-induced Foxp3 inhibits T(H)17 cell differentiation by antagonizing RORgammat function. Nature 453, 236-240. doi: 10.1038 /nature06878

Zhuang, Y., Peng, L. S., Zhao, Y. L., Shi, Y., Mao, X. H., Guo, G., et al. (2012). Increased intratumoral IL-22-producing CD4(+) T cells and Th22 cells correlate with gastric cancer progression and predict poor patient survival. Cancer Immunol. Immunother. 61, 1965-1975. doi: 10.1007/s00262-012-1241-5

Zindl, C. L., Lai, J. F., Lee, Y. K., Maynard, C. L., Harbour, S. N., Ouyang, W., et al. (2013). IL-22-producing neutrophils contribute to antimicrobial defense and restitution of colonic epithelial integrity during colitis. Proc. Natl. Acad. Sci. U.S.A. 110, 12768-12773. doi: 10.1073/pnas.1300318110

Conflict of Interest Statement: The authors declare that the research was conducted in the absence of any commercial or financial relationships that could be construed as a potential conflict of interest.

Copyright (c) 2016 Parks, Pociask, Hodzic, Kolls and Good. This is an open-access article distributed under the terms of the Creative Commons Attribution License (CC $B Y)$. The use, distribution or reproduction in other forums is permitted, provided the original author(s) or licensor are credited and that the original publication in this journal is cited, in accordance with accepted academic practice. No use, distribution or reproduction is permitted which does not comply with these terms. 